\title{
Kapitalismens alder og vitalitet
}

\author{
Thomas Andersen, Jens Herskind og Hjalte Tin Iversen
}

\section{FORORD}

Denne artikel er en opfordring til diskussion med Kurasjes læsere og skribenter, om hvordan man undersøger kapitalismens alder og vitalitet. Alle marxistiske skribenter op til nu, og før Marx, de gamle utopiske socialister, har gjort sig forestillinger om kapitalismens alder og vitalitet. Disse forestillinger har på den ene eller anden måde givet arbejdet et perspektiv. Marx sad oppe til langt ud på natten og nedkradsede sit grundrids til kritikken af den politiske $\varnothing$ konomi, for at få det færdigt inden "the great deluge", som han forestillede sig måtte blive udgangen på krisen i 1857. Senere talte Lenin om kapitalismens råddenskab og bortdøen i finanskapitalens tidsalder. Mange tænksomme og dygtige marxister troede, at krisen i trediverne var "dødskrisen" - osv. Idag er vi på mange planer af vores dagligdag langt mere undertrykt og fremmedgjort af "kapitalismen" end Marx var i Soho. Hvad er det for en "kapitalisme" der har disse Fønixevner, der gang på gang snyder sine mest indsigtsfulde kritikere og genopstår, forstærket og udvidet?

Det er klart at sammenhængen mellem kapitalisme som historisk virkelighed og som begreb, er vanskeligere tilgængeligt end som så. Hvad er "kapitalisme"? Hvor, hvordan og hvad er dens opståelses- og reproduktionsbetingelser? Hvad indebærer Marx' begreb om kapital(isme)? Disse tilsyneladende forlængst afklarede spørgsmål vil vi nu tage op og vise, hvordan vi når frem til en række helt afgørende specifikationer af de gængse og forkortede opfattelser, ved at specificere kategorierne dialektisk, dvs. ud fra deres historiske tilblivelse igennem subsumtion.

Når Marx nu starter Kapitalen med analysen af varen, er det selvfølgelig fordi varen er den kapitalistiske produktionsmådes nucleus, dens elementære moment. Hele den marxistiske sekundærlitteratur har bemærket dette. Tilsvarende er vareanalysen det elementære moment i den dialektiske erkendelse af den kapitalistiske produktionsmåde. Dette er stadig sandt, osse når man ikke kan finde ud af, hvordan varen og verdenskapitalismen, og tilsvarende, vareanalysen og erkendelsen af den konkrete totalitet, hænger sammen. Når en "marxist" kaster vareanalysen på møddingen, er det ikke fordi vareanalysen 
er ubrugelig i erkendelsen af verdenskapitalismen, men fordi "marxisten" er uduelig. Vejen til erkendelsen af den konkrete totalitet, og hermed af kapitalismens alder og vitalitet, starter med vareanalysen og ikke i et krav om "anvendelige" analyser.

Når det ser omvendt ud for mange mennesker skyldes det en forvirret og forkert opfattelse af forholdet mellem marxisme og revolution. Marxismen er ikke revolutionær; den er en kritik af den politiske økonomi (det borgerlige samfunds selvforståelse), og revolutionen er ikke marxistisk; den er virkeliggørelsen af kommunismen. Marxismen er som individuel erkendelse bundet til sit objekt, det borgerlige samfund, hvad dens status af videnskabelig (i Marx' forstand) kritik ikke forandrer. Derimod er revolutionen en kollektiv erkendelse, som i sagens natur bliver virkeliggjort som den revolutionære udvikling af det nye samfund, og ikke som en videnskabelig teori. Kun det kollektive subjekt kan overskride kapitalismen som den objektive historiske begrænsning for menneskers daglige liv. Det individuelle subjekt kan kritisere, mere eller mindre videnskabeligt, at kapitalen er denne historiske epokes objektive subjekt, men aldrig alene ændre dette forhold. ${ }^{1}$

Hvordan en marxist, eller ethvert andet menneske, går fra en teoretisk kritik af kapitalismen til en praktisk udvikling af kommunismen, kan marxismen ikke besvare, heller ikke hvis den gøres "anvendelig", til "realanalyse" eller "partitro". Det kan man kun finde ud af ved at oprette en fantasifuld alternativ virkelighed. Den fantasi, der skal til for at oprette en alternativ virkelighed, er helt forskellig fra den fantasi, der skal til for at føre den dialektiske fremstilling af det borgelige samfund fra varen til verdensmarkedet. Således må en marxist for at være med til at oprette den nye virkelighed gå på to ben. ${ }^{2}$ Her drejer det sig om at gå fra varen til verdensmarkedet. Den anden fantasi udfolder vi i Solvognen, på Christiania og hvad der kommer efter, sammen med vores børn og kærester.

Altså: fra varen til verdensmarkedet, og derfra skue ud over kapitalismens alder og vitalitet. Alt det arbejde og alle de overvejelser artiklen her sammenfatter, kan formuleres ganske kort: Ethvert dialektisk begreb er en tankemæssig rekonstruktion af en virkelig historisk bevægelse. Og det betyder for alle os,

1. Vi har fors $\emptyset \mathrm{gt}$ at beskrive vilkårene for individuel og kollektiv erkendelse $\mathrm{i}$ sidste afsnit af vores rapport, Hellere Stort og Halvbagt end Lille og Afbrændt, Statens Historie år 1000-2000, Del 2. Fra absolutistisk kongestat til merkantil borgerlig stat. Englands historie i overgangen fra feudalisme til kapitalisme, år 1550-1750, Roskilde Universitetscenter, 1977, s. 338-372. (Herefter: Statens Historie, del 2). Rapporten kan lånes på Roskilde Universitets Bibliotek.

2. Vi præciserer dette i afsnittet "Marxisme og Revolution" (se note 1). Den vigtigste opgave for marxisten er den samme som for alle andre mennesker: deltag i det daglige livs kamp mod værdilovens tvang, der hvor den rammer din tilværelses kollektiver. Sekundært er det marxistens opgave at kæmpe i den borgerlige offentlighed for at vække den kollektive, historiske erfaring om tidligere og samtidige kampe mod udbytning og undertrykkelse. Selve den marxistiske teoriudvikling er for os, som for Paul Mattick, en hobby (se Kurasje, nr. 12, s. 71). 
der arbejder på grundlag af Karl Marx’ resultater, at vi må specificere hvert eneste af hans begreber ud fra deres tilblivelse og reproduktion i historien. Ad denne vej kan vi videreudvikle den dialektiske fremstilling af varesamfundenes historie.

Vi opfatter selv vores arbejde som led i den "videreudvikling af kritikken af den politiske økonomi" vores gamle kollega Jens Henning Rasmussen taler om i sin kritik af Hans Jørgen Schanz "Anti-kritik". ${ }^{3}$ Vi er helt enige med JHR i hans kritik og mener osse, at Schanz er kommet ud i en ørken med sin "metateori" om marxismen. Selvom Schanz har mange gode punkter, især hans overvejelser om forholdet mellem udbytning og undertrykkelse, er det sælsomt at se, hvor umuligt det er for ham at komme ud over textens udlægning, og igang med en selvstændig videreudvikling. At Schanz kan få sig selv til at ende med de helt tomme sociologiske "aspektopdelinger", der er et tilbageskridt fra "omfangslogikkens" forsøg på at udvikle subsumtionsbegrebet, kan vi kun forklare ud fra hans manglende arbejde med den virkelige historie. ${ }^{4}$ Vi skal i næste afsnit skitsere et dialektikbegreb, der er mere radikalt end det Schanz har læst sig til hos Marx. Det er istand til at løse Schanz problem med subsumtionen (osse af "produktionseksterne områder"), fordi det er baseret på en anden opfattelse af forholdet mellem historie og logik (emperi og "kapitalen i almenhed") og af abstraktionernes "real-status". Vi vil opfordre Schanz til at bruge sine evner på at begrebsliggøre historien og ikke kun historisere begreberne. Når vi gør det, er det fordi vi selv har oplevet - da vi i sin tid gik igang med Marx - hvor inspirerende og igangsættende det "kapitallogiske" 5 udgangspunkt var for den historiske specificering af den marxistiske kritik af kapitalismen.

På den anden side er vi fundamentalt uenige med JHR i hans forslag til hvordan man kommer ud over Schanz begrænsninger. Problemet består ikke i at færdigskrive 3. bind af "Kapitalen", for endelig at nå frem til klassekampen. Derimod er problemet at kritisere og blive færdig med metafysikken i marxismen. Metafysikken i marxismen har to kilder, dels problemet med Hegel hos Marx, og dels marxismens ufolkelige udvikling (ufolkelig hos statspartierne i øst og vest, ufolkelig på universiteterne i øst og vest). ${ }^{6}$ Metafysikken er et spøgelse der har hjemsøgt alt for meget arbejde med marxismen. På Kurasje fx i de tyske forsøg på at løse "realanalyse problemet", i Reichelts udlægning af kapitalbegrebets logiske struktur, hos Schanz, Marquart, osv. Den bun-

3. J. H. Rasmussen: Hvad skal vi med Kapitallogikken? i Kurasje nr. 17.

4. H. J. Schanz: Antikritik, Modtryk, 1977, s. 88-107.

5. Og lad os kalde en spade en spade og dialektik dialektik. Den pædagogiske hensigt med opfindelsen af "kapitallogik" er slået fejl, og det er på tide vi igen gør krav på hele MARXISMEN og ikke kun en kapitallogisk fraktion af den marxistiske kapitalismekritiks landvindinger.

6. At Mattick netop er fri for denne metafysik skyldes givetvis, at han hverken er partiideolog ellerr akademiker. 
der i en fundamentalt forkert opfattelse af abstraktionens plads og funktion i marxismen. Abstraktionen er ikke, som fx. Sohn-Rethel tror, noget realt der udspringer af bytteværdien, men tværtimod et fortælleteknisk fif man anvender i den sociale videnskabs laboratorium. Hvordan, skal vi se i næste afsnit. Altvater vil aldrig slå bro fra kapitalen i almenhed til det reale (statestikken), og JHR vil aldrig nå frem til klassekampen igennem "realanalysen". Det skyldes at de er gledet fra moment/totalitet til fremtrædelse/væsen. Den konkrete totalitet er den fuldstændige tankemæssige rekonstruktion af varesamfundets globale historie. Denne dialektiske fremstilling er konkret, og det er momentet i den konkrete totalitet osse. Når den konkrete totalitet kan blive til et "væsen" og derigennem (real)abstrakt, er det fordi man ikke gør sig klart hvordan man forkorter den konkrete totalitet. Det forklarer vi nedenfor. Problemet med videreudvikling af kritikken af den politiske $\varnothing$ konomi er altså ikke at videreudvikle væsenskategorierne opnedudind til klassekampens toilet, men derimod at gøre op med væsenslogikken og forkorte den konkrete totalitet til noget der kan rummes i et marxists hoved. Pga. Marx' sygdom og død er "Kapitalen" på mange måder en tilfældig forkortelse af den konkrete totalitet. Den skal ikke skrives færdig, men skrives om på ny. Det gælder ikke om at finde nye "formidlingskategorier", men at specificere Marx' kategorier på en langt mere omfattende historisk måde end han selv nåede.

Efter denne svada kan det vel ikke undre, at artiklen er bygget op som en historisk udvikling af subsumtionsbegrebet, dvs. ud fra historiske data og ikke Karl Marx' værker. Artiklen er delt i to hovedafsnit, først et om penge og dernæst et om kapital. Forud for afsnittet om penge er der en indledning, hvor vi forsøger at redegøre for subsumtionsbegrebet og dets udvikling som en konsekvens af opgøret med væsenslogikken. Det drejer sig altså om to ting, dels subsumtionsbegrebet i forhold til modsigelsen væsenskategorier/historisk emperi, og dels i forhold til modsigelsen konkretabstrakt. Afsnittet om penge viser hvordan subsumtionens grundform udvikles med vareformen. Vi fors $\emptyset$ ger at vise, hvordan pengeformen udvikles som et "kontinuum" af enkle subsumtioner (oprettelserne af vareformen i den stadige småhandel), der gør ædelmetallet til bærer af en samfundsmæssig relation. Med "kontinuummets" udvikling er der opstået mulighed for den fundamentale transformation i feudalismen: opståelsen af staten. Vi viser hvordan kontinuummet (af enkle subsumtioner) gennemfører den komplexe subsumtion af den feudale kongemagt. Den feudale kongestat opstår. Afsnittet afsluttes med en fremstilling af den komplexe subsumtion af den feudale kongemagt i analogi til vareanalysen. Varen, pengene og statens første form skal specificeres ud fra deres tilblivelse i den europæiske middelalder, der er kapitalismens umiddelbare forudsætning (hvad varer, osv. i andre historiske epoker ikke er). Den lange historiske proces frem til overgan- 
gen til kapitalisme er presset sammen til et par sider som en kort henvisning til vores egentlige empiriske arbejde med arktiklens område. ${ }^{7}$ Afsnittet om kapital har to dele. Dels det centrale afsnit om branchen som kapitalismens mindste virkelighed, hvor vi forsøger at give en historisk specifikation af kapitalens opståelse og reproduktionen. Det er klart, at vi hermed kommer ind på overgangen fra feudalisme til kapitalisme. Det er dog ikke vores ærinde her, og vi refererer kun kort til vores empiriske arbejde. Endvidere korresponderer vores diskussion kun med tiden frem til ca. 1730 i England, altså ikke den industrielle revolution og frem. Vi antyder hvordan branchen bliver moment $i$ et ny kontinuum, og hvordan dette kontinuum 2 gennemfører en komplex subsumtion af den historisk overleverede statsform (den merkantile borgerlige stat) og den første kapitalistiske stat opstår. Dels afsnittet om guld og penge, hvor vi giver et historisk rids af guldets betydning for pengeformens udvikling op til idag, hvor guldet er gået ud af pengeformen. Afsnittet om kapital afsluttes med en diskussion om verdenspenge, hvor vi fors øger at skitsere den nye almene ækvivalent baseret på den kapitalistisk producerede arbejdskrafts internationale produktivitet. Artiklen afsluttes med en diskussion af Christel Neusüss, hvor vi skitserer vores opfattelse af verdensmarkedets struktur idag og vender endelig tilbage til artiklens udgangspunkt: kapitalismens alder og vitalitet. Her trækker vi den konklusion, at verdenskapitalismen stadig har den enorme udviklingsmulighed, der ligger i overvindelsen af den feudale nationalstat og udviklingen af en form for "ultra-imperialisme", hvis atomkrigen ikke har sat en stopper for den kapitalistiske ekspansion. Eller en proletarisk verdensrevolution...

7. Statens Historie del $1 \& 2$. Se note 1 og 19. 


\section{INDLEDNING: SUBSUMTIONENS ABC}

\section{A. Den ortodoxe definition af subsumtion: vasen/subsumtion/fremt- rædelse}

Visse historiske bevægelser, diskontinuiteter, korresponderer med det Marx kalder "økonomiske former". Det er klart, at det ikke er enhver historisk bevægelse, der korresponderer med en økonomisk form. Uden nærmere diskussion drejer det sig om diskontinuiteter i varesamfundenes historie. Denne historie er een stor flade af punkter, der kan rekonstrueres af tanken, ved at de får et navn eller gøres lig med et begreb. Ikke alle punkter er diskontinuiteter og ikke alle begreber er dialektiske. Subsumtion er den modsætningsfyldte historiske proces, der opretter og reproducerer en $\emptyset$ konomisk form. I den tankemæssige reproduktion eksisterer de samme modsætninger i den dialektiske overgang, der opretter og reproducerer et dialektisk begreb. Der er en strukturel identitet mellem den historiske diskontinuitet, der skaber en økonomisk form - og så den dialektiske overgang der skaber et dialektisk begreb. Denne identitet mellem en historisk proces (diskontinuiteter i varesamfundene) og tankemæssig reproduktion (dialektisk overgang i marxismen) kalder vi subsumtion, eller vi siger, at identiten skyldes subsumtion.

"Subsumtion" kan vi altså definere dobbelt: som en historisk modsætningsfyldt proces, hvor to konkrete instanser (brugsværdier eller sociale strukturer) bliver underordnet/del af varesamfundenes sociale sammenhæng; og som en tankemassig proces, hvor den historiske subsumtion reproduceres som en dialektisk overgang i fremstillingen af varesamfundene. Den logiske konsekvens af denne definition er at enhver dialektisk overgang forud har en historisk eksistens. Vareformen er subsumtionens grundform og vareformens historiske udbredelse svarer til subsumtionsanalysens mulige omfang. "Varesamfundet" er derfor ikke nogen produktionsmåde overhovedet, og siger ikke $i$ sig selv noget om vareformens betydning for en given produktionsmådes udbytning og undertrykkelse. Varesamfundet strækker sig altså over flere produktionsmåder og subsumtionsanalyse indskrænker sig altså ikke kun til den kapitalistiske epoke. Omvendt er det indlysende, at en subsumtionsanalyse, der ikke reflekterer forholdet til de givne produktionsmåder, er ren skematik.

Subsumtion er et begreb Marx ikke anvender systematisk - ud over visse begrænsede områder (arbejdets formelle og reelle subsumtion). Det er ikke desto mindre centralt for marxismen, fordi subsumtionen altså er den historiske bevægelse, hvorigennem det vareproducerende arbejdes "indre modsætning" har historisk eksistens ("fremtræder"), hvad enten det er i form af varebytte, vareproduktion, lønarbejde, profitrater eller andre momenter i den konkrete totalitet. 
Alle momenter i den konkrete totalitet er skabt ved subsumtion og reproduceres ved subsumtionens reproduktion. Subsumtionen specificerer formidlingen mellem den historiske virkelighed og tankemæssigt rekonstruerede historie. Det skyldes, at subsumtionerne er de punkter i varesamfundenes historie, hvor den "indre modsætning" mellem "abstrakt samfundsmæssigt" arbejde og konkret arbejde eksisterer reelt - virkeligg ør sig i menneskenes verden, forvandler dens videre udvikling.

Præcis på dette punkt konkluderer Larsen \& Schanz: "Idet pengeformer opdages som på engang den eneste måde, hvorpå værdien kan fungere punktuelt og ligeledes fremtræde punktuelt, samtidig med at denne funktion og fremtrædelse netop skjuler sin sande, objektive begrundelsessammenhæng, så bliver indstillingen til den på vardi og kapital beroende emperi vasenslogisk." ${ }^{8}$ De stiller sagen korrekt op, men trækker den forkerte konklusion, hvad vi skal se.

\section{B. Emperien skjuler intet, der er ingen vasner i historien. Modsigelse mellem den ortodoxe væsenslogik og emperien}

Den virkelige historiske dagligdag har ikke nogen dybde mellen en "indre" struktur eller "væsen" og en "ydre" "fremtrædelse", men kun en ubrudt strøm af realiteter. Det er en fundamental sandhed. Derfor er væsenslogikkens materialisme en dårlig materialisme, en nødløsning på den individuelle erkendelses problemer. Vi vil ikke diskutere dette mere, for det er fremmed for marxismen at forestille sig en empirisk, historisk eksistens af oversanselige væsner.

Det er et indlysende og uomgængeligt krav til den dialektiske rekonstruktion af historien, at den kan specificere hvert eneste begreb som en konkret tankemæssig rekonstruktion af en virkelig historisk bevægelse.

Det er altså vores store problem, som marxister idag, at vi på den ene side har en tradition for at opfatte Marx værdibegreber som "væsens-kategorier", mens vi på den anden side ikke har nogen vidnesbyrd om "væsner" i vores historiske forskning (for ikke at sige vores dagligdag). Det er ikke kun et polemisk problem, men det fundamentale problem, at forholdet mellem historie og logik ikke er løst tilfredsstillende endnu.

\section{Modsigelsen mellem væsenslogikken og emperien ophæves i den konkrete totalitet. Her er den dialektiske fremstilling konkret}

Den virkelige historie opløser selv modsigelsen mellem "indre modsætning" og éndimensional historisk struktur, i de punkter hvor den "indre modsætning" er

8. M. Larsen og H. J. Schanz: Oversætternes Forord i Karl Marx: Grundrids, Modtryk/Kurasje, 1974, s.xxx. 
reel i et forhold mellem to konkrete instanser. Det sker altså i subsumtionsbevægelsen. Den tankemæssige rekonstruktion af alle subsumtionsbevægelserne udgør den konkrete totalitet.

Når Marx derfor siger: "For mig er det omvendt det ideelle (den konkrete totalitet, HTJ) intet andet end det i menneskehovedet omsatte og oversatte materielle." - så er det kun rigtigt under én forudsætning: at menneskehovedet er i stand til at fremstille det ideelle, dvs. den konkrete totalitet. Men den fuldstændige og komplette rekonstruktion af varesamfundenes globale historie i dets milliarder af detaljer er både uinteressant og umulig for den individuelle erkendelse.

\section{Modsigelse mellem fremstillingen af den konkrete totalitet og marxismens praktiske muligheder}

Når vi omtaler den konkrete totalitet, er det fordi den kan bruges til at vise, at den dialektiske fremstilling $i$ sig selv er ikke-abstrakt, men tværtimod een stor flade af konkrete rekonstruktioner af subsumtionshistorier by the billion. For at kritisere de metafysiske "væsner", er vi nødt til at starte med den konkrete totalitet, for at afvise at abstraktionen hører hjemme i den dialektiske fremstilling. Derefter vil vi så se på den konkrete totalitets produktionsbetingelser, som netop er betingelserne for den individuelle erkendelse. Vores argumentation er derfor omvendt i forhold til gangen i den praktiske marxismes analyser. Det leder frem til en modsigelse mellem den konkrete totalitets umådelige omfang og den individuelle erkendelses praktiske muligheder.

\section{E. Den praktiske marxisme er nødt til at forkorte den konkrete totalitet}

For os, som en praktisk udfordring og opgave, er den dialektiske fremstilling af den konkrete totalitet, fremstillingen af en forkortet udgave af den ideelle, totalitet. Derfor er vores argumentation omvendt i forhold til den praktiske analyses gang. I praksis forkorter vi selvfølgelig ikke den konkrete totalitet, men når efter analysen frem til en fremstilling, der reelt er en forkortet konkret totalitet. Problemet er altså ikke: hvordan får vi "formidlet" vores kapitalbegreb op til dagligdagens klassekamp osv., men tværtimod hvordan forkorter vi vores ideelle fremstilling, så den alligevel fortsætter med at være konkret? Fx. tror vi, at vore mange kollegaer, der har arbejdet med danske forhold, hellere skulle bekymre sig om, hvordan de kan opretholde en dialektisk national begrænsethed end bevise, at det er "kapitalen i almenhed", der står bag det politiske livs cirkus.

9. Marx: Das Kapital, MEW 23, s. 27. 


\section{F. Væsenslogikkens blinde øje. Metafysikken exorceres fra marxismen}

At væsenslogikken har et blindt øje ser vi, når den tillader enhver marxist at sætte sig i besiddelse af den konkrete totalitet. Forholdet mellem individuel og kollektiv erkendelse har væsenslogikken aldrig præciseret, bla. fordi den har forudsat sin egen fremtrædende rolle i revolutionen. Den har begået den småborgerlige fejl at tro, at massernes revolution vil være en gentagelse af den filosofiske kapitalismekritik. ${ }^{10}$ Det er en bedrøvelig og afgørende fejl.

Larsen \& Schanz konkluderer det tidligere citat: "..den på værdi og kapital beroende emperi (bliver opfattet) væsenslogisk, hvilket kort vil sige, at den værdi - og kapitaldeterminerede overflade (emperien) ikke i sig selv tages som sidste udsagn, ikke tages som en samling stenhårde data, som teorien enten blot skal organisere og generalisere, eller som teorien blot skal føre tilbage på et historisk invariabelt begreb for produktivkraft og produktionsforhold; tværtimod tages emperien som det nødvendige, såvel funktionelle som repræsentative udtryk for de på værdiproducerende arbejde beroende væsensbestemmelser og lovmæssigheder, som til gengæld netop ikke kan hverken fremtræde eller fungere umiddelbart." ${ }^{11}$ De siger fordrejet, skjult og dermed væsen/fremtrædelse. De placerer kort sagt fordrejningerne som en kvalitet i objektet for erkendelsen, de $g \varnothing r$ det til en kvalitet ved varesamfundene og især kapitalismens produktionsmåde.

Vi drager den modsatte konklusion: at fordrejelserne osv. ikke er en kvalitet ved objektet, men ved subjektet. Dvs. at det ikke er en kvalitet ved emperien i sig selv, men ved den, der erkender - eller mere præcist, at fordrejningerne opstår, når et bestemt subjekt (individet) skal tilegne sig et bestemt objekt (varesamfundenes globale historie).

For det kollektive subjekt er disse problemer kun sofisterier. Den kollektive erkendelse er praktisk og ikke teoretisk. Her er muren mellem erkendelsen som tankeprodukt og erkendelsen som praktisk forandring brudt ned; her forsvinder enhver tale om væsner osv. Vi mener derfor at væsenslogikken, og dermed en form for metafysik i marxismen, kommer af, at den individuelle erkendelse prøver at lege kollektiv erkendelse. Det er dette fors $\emptyset \mathrm{g}$ på at overskride det tænkende hoveds fysiske og sociale begrænsning, der af væsenslogikken artikuleres som væsnets "real-status". Men det reale - virkelige - i denne sag er ikke "væsnet", men den fysiske og sociale forskel på det individuelle og kollektive subjekt.

10. Hør f.eks. Larsen \& Schanz: " . først med erkendelsen af det kapitalistiske samfunds grundlæggende reproduktionsbetingelser, kan den marxske teori levere grundlaget for en kapitalnegerende revolutionær strategi .." Larsen \& Schanz op. cit. s. xxxii.

11. Larsen \& Schanz op. cit. S.xxx. 
Når alt dette er sagt, står der altså et faktum tilbage: at marxismens praktiske betingelser er det individuelle subjekt, og at det ikke kan fatte totaliteten konkret; hvordan kan vi så opretholde argumentet om, at modsigelsen mellem væsnet og emperien ophæves i den konkrete totalitet?

\section{G. Modsigelsen mellem konkret totalitet og nødvendig abstraktion. Abstrak- tionskraftens funktion i marxismen}

Væsenslogikken forvandler moment/konkret totalitet til fremtrædelse/væsen, men det er en metafysisk måde, hvorpå det "tænkende hoved" kan tilegne sig "denne verden"12; det kan ikke omslutte den konkrete totalitet, men må rejse fra det konkrete kaos, empirien, via det abstrakte (på en måde vi uddyber om lidt) til det "tankekonkrete", "tanketotaliteten", den konkrete "totalitet" 13 . Elegant kan man så komme til at forvandle grundlaget for den marxistiske kritik af kapitalismen fra den konkrete totalitet, til et aksiomatisk, metafysisk væsen.

Problemets metodiske omfang kan indsnævres til "abstraktionskraftens" funktion i "analysen af de $\varnothing$ konomiske former" ${ }^{14}$. Modsigelsen mellem abstraktion og konkret teoretisk rekonstruktion, kan kun opløses ved at forholdet mellem historiens og fremstillingens tidsdimensioner tages med i overvejelserne.

Den dialektiske fremstilling opløser således modsigelsen mellem konkret og abstrakt teori, ved at være i stand til at specificere alle sine begreber ud fra de virkelige subsumtionsbevægelser. Det er den uforkortede dialektiske fremstilling: hver evig eneste subsumtion ført til bogs i en ufattelig lang række rekonstruktioner. Denne fremstilling er som sagt, ikke abstrakt, fordi den netop er en uforkortet rekonstruktion. Den vil aldrig blive lavet, fordi det ville være komplet idiotisk, fx. at bogføre hvert eneste varebytte i historien. Den dialektiske fremstilling er altså $i$ sig selv ikke en abstraktion, men en konkret teoretisk rekonstruktion.

Dette gjaldt den ideelle dialektiske fremstilling (den konkrete totalitet). For den praktiske marxisme er problemet derfor at forkorte den konkrete totalitet: at skille fremstillingens tid fra historiens tid - uden at sætte den ideelle fremstillings specifitet overstyr. Den ideelle fremstilling blev specificeret igennem den tankemæssige rekonstruktion af de virkelige subsumtionsbevægelser. Den praktiske fremstilling må vise, at der over tid opstår nye former for subsum-

12. Marx: Grundrids, GrMK, s. 21, 1.30-31.

13. Ibid. s. $21,1.25-26-27$

14. MEW 23, s. 12. 
tioner. Dvs. at fremstillingen af længere tidsrum må koncentrere sig om udviklingsgangen i de "økonomiske former" og derfor se bort fra den gentagne katalogisering af de ens subsumtioner.

Abstraktionskraftens funktion i marxismen er altså at adskille historiens og fremstillingens tider.

\section{H. Abstraktionerne er en metode til at forkorte, en tidsaccellerator}

Subsumtionen er, som nævnt, den historiste bevægelse hvorigennem "den indre modsætning" mellem brugsværdi og værdi er reel i et "ydre" forhold mellem to konkrete instanser. Ideen om den "indre modsætning" i en given økonomisk form, er i sig selv abstrakt og udgør en hjælpeforanstaltning i fraværet af den uforkortede dialektiske fremstilling. Således er et begreb som "en vare alene i verden" ikke dialektisk, men abstrakt fordi varens "indre modsætning" mellem værdi og brugsværdi kun har historisk eksistens i værdiforholdet mellem to varer. ${ }^{15}$ Som dialektisk kategori er én vare en uting. Den virkelige historiske bevægelse kan nemlig ikke isolere den ene side i modsætningen mellem værdi og brugsværdi.

Abstraktionens funktion i den dialektiske fremstilling kan vi derfor opfatte som en accellerator, der tilsættes stoffet for at komme hurtigere frem, dvs. for at adskille fremstillingens tid fra den historiske tid. Denne abstraktion abstraherer brugsvardierne til formelle fælleskategorier, - den mest omfattende er netop "brugsværdi". Denne abstraktion er formel og ikke reel.

Vi kan måske klargøre dette med et eksempel. Hvis vi tar et dialektisk begreb som "en vare", så specificeres det af den konkrete subsumtionshistorie, der frembragte denne $\varnothing$ konomiske form - jeg lægger en tier på disken og får et motorcykelblad. To konkrete instanser bringes i den sociale situation vi kalder "et værdiforhold". Dette værdiforhold er et moment i den konkrete totalitet - eet blandt milliarder. Så siger vi: vareformen, og abstraherer både gennem tiden og fra egn til egn og mener både mit blad og din hest osv. Larsen \& Schanz uddyber: "For fremstillingsmåden er det afgфrende, om Erscheinung er en "Erscheinung für es" eller alene "für uns" . ${ }^{16}$ "En vare" er totaliteten pr. moment for os, og som sådan konkret, mens "vareformen" er alle varerne (totaliteten) for sig selv; her eksisterer totaliteten som en relation til sig selv og samtidig abstrakt for os, som varernes $\varnothing$ konomiske form uden de mange brugsværdier.

15. Jvf. Marx, Grundrids, Gr/MK, s. 21, 1.17-18: "(Bytteværdien) kan udelukkende eksistere som abstrakt, ensidig relation inden for et allerede givet konkret, levende hele".

16. Larsen \& Schanz op. cit. s. 1. 


\section{Subsumtionen i den forkortede totalitet}

Vi vil som konsekvens af vores overvejelser om subsumtionen og abstraktionskraften afvise den almindelige forestilling om "real-abstraktionerne", fordi den 1) opretter et væsensniveau i den historiske realitet, der aldrig vil kunne frigøre sig fra Hegels metafysik, 2) Marx' brug af abstraktionen, "det vigtigste instrument i den sociale videnskabs laboratorium", som han siger i Kapitalens forord, indikerer ikke at skulle have realstatus, netop fordi 3) værdikategorierne er specifikationer af virkelige sociale relationer (historiske diskontinuiteter), mens abstraktionerne gælder brugsværdierne. Modsætningen mellem den "abstrakte" værdi, og den "konkrete" brugsværdi opløses i den virkelige historiske bevægelse igennem tidsfaktoren.

Det er iøvrigt, indlysende nok, bedst udviklet i den marxistiske diskussion i forbindelse med krisecyklen, hvor netop tidsfaktoren er afgørende (den historiske dimension). Modsigelsen mellem abstrakt og konkret opløses i forholdet mellem moment og totalitet, hvor totaliteten for det erkendede individ altid må være tilstede i teoretisk form, kun kan fattes ved hjælp af abstraktionskraften, mens totaliteten for det kollektive subjekt er en praktisk realitet, der kan forandres.

Hvis vi skal opsumere vores overvejelser om subsumtionen, så er det vigtigste resultat at væsenslogikken afvises som "real-logik" osv. Så når Marx taler om, at alting fremtræder fordrejet i konkurrencen, skal det efter vores mening opfattes som en $n \phi d v e n d i g$ fordrejning, der indtræder, når det individuelle subjekt forsøger at omslutte den konkrete totalitet i hovedet. Hermed er der sagt to ting, dels at den konkrete totalitet ikke er abstrakt, og dels af den må forkortes ved hjælp af abstraktionskraften når det individuelle subjekt skal fremstille den.

En marxisme uden væsenslogik adskiller sig først og fremmest fra "kapitallogisk" marxisme i dens politiske implikationer, dvs. i opfattelsen af forholdet mellem marxisme og revolution. For marxisten er den en udfordring til rekonstruktion af subsumtionshistorier - en historisk specificeret marxisme, Marx' værdikategorier skal ikke afskaffes, de skal specificeres historisk.

\section{J. Den politiske konsekvens af opgøret med væsenslogikken}

For os er der osse en politisk betydning i afvisningen af væsenslogikken og dens "real-abstraktioner", som rækker ud over den nuværende metodiske diskussion: den magt den borgerlige offentligheds arbejderledere har til at definere hvad der er (den rette) politik, er altid begrundet i abstrakte argumenter om kapitalismens (samfundets) "natur", dvs. den konkrete totalitet. Det kan de komme afsted med fordi marxismen stadig mangler et konsekvent opgør med 
metafysikken. I praksis er metafysikken i marxismen et videnskabeligt forsvar for, at de manges praktiske erfaringer underordnes de fås abstrakte erkendelse.

På denne måde kunne marxismen blive til "marxismen-leninismen og en statsideologi. Således er de fås metafysiske marxisme en undertrykkende statsideologi, mens de manges praktiske "marxisme" er en destruktion af staten: "Statens iboende tendens er at koncentrere, at indsnævre og monopolisere alle sociale aktiviteter; i modsætning hertil er revolutionens natur at vokse, udvide og udbrede sig selv i stadig større cirkler. Med andre ord, staten er institutionel og statisk, revolutionen er flydende, dynamisk. Disse to tendenser er uforenelige og gensidigt destruktive. Statsideen dræbte den russiske revolution, og resultatet må blive det samme i alle andre revolutioner, såfremt emancipationens ide (the libertarian idea) ikke sejrer." - sagde Emma Goldman i 1923. ${ }^{17}$

\section{AFSNITTET OM PENGE}

\section{A. Den feudale kongestat Enkel subsumtion - Kontinuum - Komplex subsumtion}

Vi har set at subsumtionen er den modsætningsfyldte historiske proces, der opretter og reproducerer en $\varnothing$ konomisk form, og videre reproduceres tankemæssigt i en dialektisk overgang.

$\mathrm{Nu}$ skal vi meget langt tilbage i tiden, helt tilbage til tiden omkring år $1000 \mathrm{i}$ den europæiske feudalisme. Det skyldes, at vi skal opspore pengenes og statens subsumtionshistorie. Statsanalysen er nødvendig for at forstå udviklingen i de andre $\varnothing$ konomiske former og er samtidig det centrale tema for vores egentlige empiriske arbejde. Begrebet om "enkel subsumtion" er reproduktionen af vareformens udvikling; begrebet om "kontinuum" er reproduktion af pengeformens udvikling og begrebet om "komplex subsumtion" er reproduktion af statsformens første udvikling.

Subsumtionens grundbestemmelser er givet i vareanalysen. ${ }^{18} \mathrm{I}$ vareanalysen drejer det sig om den konkrete totalitets (det kapitalistiske samfunds

17. I efterordet til My Disillusionment in Russia, 1923, citeret i Living My Life, New American Library, 1972, s. 719.

18. Selve vareanalysen har vi efterhånden gennemdiskuteret, og vil ikke bruge pladsen her til det. Se Til Grundlaget for Bestemmelsen af Fagkritikken i Senkapitalismen, RUC, 1974, s. 1-25; Tale er Tavshed Guld er Sølv. Den borgerlige stats subsumtionshistorie: den feudale kongemagt, den feudale kongestat, den absolutistiske kongestat frem til den Engelske Revolution i 1640, RUC, 1976, s. 1-29. (Herefter: Statens Historie, del 1). Rapporterne kan lånes på RUB; Den borgerlige stats subsumtions historie - den feudale fase. Historievidenskab nr. 10-11, s. 34-42; Statens Historie, del 2, s. 1-13. 
erkendte virkeligheds) mest enkle momenter, nemlig vareformerne. Vareanalysen viser, hvordan "værdisubstansen" kun kan fremtræde igennem subsumtionen af en specifik genstand, brugsværdi. Den mest simple subsumtion er således oprettelsen af værdiens ækvivalentform. Denne simple tilfældige værdiform er overhovedet den mest enkle værdiform og kan som sådan eksemplarisk fremstille enhver dialektisk konstitutions grundbestemmelser: en dialektisk form, som vareformen, kan kun hænge sammen, har historisk eksistens ved, at dens indre modsætning, her mellem værdi og brugsværdi, bevæger sig som en ydre modsætning mellem to historisk konkrete instanser, her to varer.

Vareformerne er af kort varighed; de gennemgår en enkelt bytteakt før de opløses, og brugsværdien ryger ud af den subsumerede tilstand, naturligvis uden at stoffet som sådan behøver at ophøre med at eksistere. Den ikke abstrakte fremstilling af disse momenter bevæger sig på brugsværdiernes niveau, dvs. på det helt konkrete niveau: det og det søm, den og den hammer; osv. Den materielle specifitet kan ikke abstraheres udenom subsumtionsanalysen, uden at blive ahistorisk og vilkårlig. Vareanalysens afgørende konsekvens er derfor, efter vor mening, at den viser hvordan Marx selv ophæver modsætningen mellem værdi og brugsværdi, og mellem abstrakt og konkret i en, omend lille, konkret totalitet. Han viser her på hvilken måde, det er muligt at begribe sammenhængen mellem værdisubstansen og materialiteten dialektisk i dens mest enkle udtryk. Dette bliver samtidig udgangspunkt og bevægelsesform for al dialektisk forståelse af den konkrete historie.

Spørgsmålet er nu, om man meningsfuldt kan fremstille andre og mere komplekse momenter i den konkrete totalitet på samme måde, dvs. ved anvendelsen af en tilsvarende begrebsliggørelse af den historiske udvikling. Det mener vi godt, man kan. Vi skal her redegøre for, hvordan vi mener, man må udvikle subsumtionsbegrebet, for at det skal blive tjeneligt til at undersøge en historisk proces som den borgerlige stats udvikling.

Udgangspunktet for undersøgelsen er den stadige repetition af ensartede kombinationer, værdiudtryk, af værdi og brugsværdi. Vareformernes gentagne oprettelse producerer en kontinuerende bevægelsesform. Denne kontinuerende bevægelsesform for værdien vil vi omtale under ét som et kontinuиm, fordi kontinuummet som sådan skaber betingelser for det næste trin i varesamfundets udvikling.

Tuskhandlen udtrykker en lille modsætning, modsætningen mellem varens brugsværdi, dvs. dens behovstilfredsstillende kvalitet, og dens værdi, dvs. dens indhold af abstrakt samfundsmæssig menneskeligt arbejde. Denne modsætning er lille og tilfældig, fordi det abstrakte samfundsmæssige arbejde kun er til i det 
tilfældige bytte og ikke på nogen måde regulerer målene i det konkrete arbejdes udveksling, som måske kun var at plukke et æble, eller at dræbe en sølvræv bag bjergene.

Andet udtrykker den enkelte enkle subsumtionshistorie ikke, og kan den ikke udtrykke. I tuskhandlen var varebytterne en gensidig tilfredsstillelse af behov uden tvang, da det udvekslede merarbejde var tilfaeldigt overskud: "Hos mange folkeslag blev disse forskellige sorter af naturaliepenge bragt ind i et fast system; således gjaldt hos indianerne i Missouriområdet: 2 knive = et par bukser, 2 knive og 1 par bukser $=1$ tæppe, det foregående +1 tæppe $=1$ ildflint, det forrige +1 ildflint $=1$ hest, det forrige +1 hest $=1$ lædertelt, det forrige +1 lædertelt $=1$ kvæg". ${ }^{19}$

Med udviklingen af tuskhandlen til pengeformidlet handel opstod der en stadig gentagelse af enkle subsumtionshistorier. En sådan handel betød, at cirkulationens konstitution var blevet samfundsmæssig med en kraft stor nok til at forvandle en specifik brugsværdi, ædelmetallet, til fremtrædelsesform for sin modsætning, bytteværdien. Man skal her være opmærksom på, at dette ikke var ædelmetallets egen bytteværdi, men alle andre varers bytteværdi. Det konkrete arbejde i varen blev til udtryk for sin modsætning, abstrakt samfundsmæssigt arbejde, og privat arbejde blev til formen for sin modsætning, arbejde i umiddelbar samfundsmæssig form. Disse forvandlinger er ejendommmeligheder ved ækvivalentformen, dvs. de er ejendommmeligheder ved pengeformidlet organisering af det adskilte, private, umiddelbare arbejdes samfundsmæssige sammenhæng. Dette gælder osse selvom pengeformen igen og igen faldt sammen og blev til skatteophobning.

Marx skriver om disse ejendommeligheder i Urtext: "Pengene er ikke blot en form, der formidler vareudvekslingen. De er en bytteværdiform, der vokser frem af cirkulationsprocessen - et samfundsmæssigt produkt, der opstår af sig selv i kraft af de relationer, som cirkulationens individer indtræder i. Så snart guld eller sølv (eller enhver anden vare) har udviklet sig som værdimål og som cirkulationsmiddel (det sidste enten i pengevarens legemelige form eller erstattet af et symbol), bliver guld og sølv til penge, uden samfundets hjælp eller villen. Pengenes magt fremtræder, som om den var en skæbne, og især under samfundsmæssige tilstande, som går under ved en mere dybtgående udvikling af bytteværdiforholdene, stritter menneskenes bevidsthed imod den magt, som et stof, en ting får overfor dem - imod det forbandede metals herredømme, der fremtræder som det rene vanvid. De gensidige sociale relationers forvandling til et fast og overvældende samfundsmæssigt forhold, der subsumerer individerne under sig, fremtræder først i pengene, og dét netop i den abstrakteste

19. F. Müller-Lyer: Phasen der Kultur, München, 1915, citeret i K. A. Wittfogel: Die Geschichte der Bürgerlichen Gesellschaft. Von ihren Anfängen bis zur Schwelle der Grossen Revolutionen, Frankfurt, 1924 (reprint 1972). 
og derfor mest vanvittige og ubegribelige form, en form i hvilken alle formidlinger er ophævet. Og dette fænomen er så meget desto mere hårdtslående, som det vokser frem af forudsætningerne om de frie, vilkårlige og atomistiske privatpersoner, som kun forholder sig til hinanden gennem de gensidige behov i produktionen". ${ }^{20}$

Bytteværdiens cirkulation, dens historiske vægt og placering er imidlertid afhængig og betinget af udbytningens form i den materielle produktion. Hvilket betyder at varehandelen, den udstrækning i hvilken "bytteværdien griber et folks produktion" ikke blot kan måles på den nominelle mængde af varebytter eller på cirkulationsomslagets givne omfang. Det væsentlige er, hvilken rolle bytteværdien indtager i udbytningens konkrete virkelighed. Det er f.eks. ikke ligegyldigt, om bytteværdien florerer blandt overklassen uden andet end et yderligt forhold til udbytningen, som under antikken; manipuleres af etnisk beslægtede handelsfolk uden om produktionen, som i merovingske og karolingske tider; eller om bytteværdien regulært indtræder som et moment i den direkte relation mellem udbytter og udbyttet. Og det er netop hvad der sker med kommuteringen under feudalismen. ${ }^{21}$

Det er den manglende forbindelse mellem varecirkulationen og selve udbytningsmåden, som altid har lammet den gamle diskussion om "monye-economy vs. natural economy", "external forces vs. internal forces", etc. ${ }^{22}$ Den langtrukne debat, f.eks., om handelens ekspansion eller ikke-ekspansion i den mørke middelalder danner ikke i sig selv nogen mening. Først sammenholdt med selve udbytningens historie, i dette tilfælde altså den feudale produktionsmådes fremkomst, får denne diskussion relevans. ${ }^{23}$ Dernæst er det en forsimplet og brutal udlægning af pengenes nedsynkning i produktionen som har præget den marxistiske historieskrivnings opfattelse af bytteværdiens historie. Det antages i en lige linie fra formuleringen af teorien om den oprindelige akkumulation, at den skinbarlige eksistens af penge i form af købmandskapital nødvendigvis sænker sig ned over produktionen og omformer den i sit eget

20. Marx: Grundrisse, EVA, s. 928 (Vores understregning).

21. Kommuteringen betegner principielt overgangen fra rene arbejdsrenter, hoveriarbejde på herremandens jord, til rene pengerenter. Herimellem ligger et væld af mellemformer, - inklusiv naturligvis naturalierenter, - med baggrund i lokale og traditionelle særtræk. Også indenfor adelens rækker kommuteredes feudale forpligtelser som riddertjeneste og edsaflæggelse til skyldigheder opgjort i penge.

22. Se f.ex. P. Sweezy: A. Critique, Science \& Society, Spring 1950. Genoptrykt i R. Hilton: The Transition from Feudalism to Capitalism, Verso Editions, 1978 (Vores oversættelse af de vigtigste indlæg i denne klassiske debat forventes at udkomme - med 2 1/2 års forsinkelse - på RUC Bogforlag i foråret 1979); M. M. Postan: The Rise of the Money Economy i Essays in Economic History, Vol I, 1944.

23. H. Pirenne: Economic and Social History of Medieval Europe, London, 1972 (1936); R. Hilton: A Comment, Science \& Society, Fall 1953. Genoptrykt i Transition ..., 1978. Baggrunden for, og omstændighederne ved feudalismens opkomst er behandlet i vores Feudalismens Rødder, RUC, 1978. Rapporten kan lånes på RUB. 
billede. (Som vi senere skal se, omfatter en oprindelig akkumulation på ingen måde blot ophobningen af pengeformuer til investering i industrialisering eller merværdiproduktion, men en akkumulation eller snarere koncentration af kommercielle aktiviteter som efterhånden danner grundlaget for fremkomsten af priskonkurrerende brancher, en ophobning af betingelserne for lønarbejde, samt ansamlingen af en borgerlig stat, som bryder med den feudale stats priviligering af monopoliseret produktion og handel). En række historiske kendsgerninger har imidlertid bragt uorden i en sådan antagelse. F.eks. har det vist sig, at områder med pludselig og livlig økonomisk aktivitet slet ikke nødvendigvis gennemgik en følgelig affeudalisering; sine steder snarere tværtimod. Rask købmandshandel og renlivet feudal udbytning trivedes udmærket side om side. ${ }^{24}$

Det bedste eksempel leveres akkurat under kommuteringens periode i England. I det 13ende århundrede var penge økonomien tilsyneladende generelt ekspanderende; udenrigshandelen voksede, markeder udvidedes. Bagom dette var kommuteringen derimod stagnerende, muligvis endda på retur. En bølge af enserfment satte ind allerede i slutningen af det 12te århundrede og krav om arbejdsrenter skærpedes op gennem det 13ende århundrede. Omvendt i det 14ende århundrede, da hele det vestlige Europa ramtes af en regulær krise som satte såvel produktion som handel kraftigt tilbage. Ikke desto mindre var det netop i det 14ende og begyndelsen af det 15ende århundrede, kommuteringen universelt satte sig igennem, hvor bytteværdiens nexus for alvor trængte ind $\mathrm{i}$ udbytningens hjerte, og stillede fæstebonden overfor herremanden som pengebesidder og vareproducent. ${ }^{25}$

Det er med andre ord ikke varehandel blot og bart, som vi søger i denne del af feudalismens tidsalder, men den varehandel, den bytteværdicirkulation som præcis med kommuteringen kom til at gennemvæve det direkte udbytningsforhold mellem herremand og fæstebonde. Principielt forvandledes hermed det samlede samfundsmæssige merarbejde til ensartet og allesteds flydende bytteværdi, mens det nødvendige arbejde, dvs. det arbejde som reproducerede arbejdskraften endnu i langt overvejende grad var brugsværdi-

24. M. Dobb: Studies in the Development of Capitalism, London, 1972 (1946), s. 38-42; M. Dobb: A Reply, Science \& Society, Spring 1950. I Transition ..., 1978, s. 61; M. Postan: The Medieval Economy and Society. An Economic History of Britain in the Middle Ages, London, 1972, s. 226.

25. Kommuteringens litteratur er omfattende. Klassiske er stadig E.A. Kosminsky: Studies in the Agrarian History of England in the Thirteenth Century, London, 1956; E. A. Kosminsky: Services and Money Rents in the Thirteenth Century, Essays in Economic History, Vol II, 1966 (1935); M. M. Postan: The Chronology of Labour Services i Transactions of the Royal Historical Society, March 1937. Om skærpelsen af livegenskabet fra sidste trediedel af 1100 tallet og frem gennem 1200tallet se f.ex. R. Hilton: Freedom and Villeinage in England i Past and Present nr. 31, 1965. En fremragende introduktion til opløsningen og fæsteformerne efter opløsningen af livegenskabet i det 14ende og 15ende årh. er R. Hilton: The Decline of Serfdom in Medieval England, London, 1969. 
producerende som subsistenskilde. Først kapitalismen inddrager denne del af den samlede samfundsmæssige arbejdsdag og producerer dermed arbejdskraft som vare.

I England satte kommuteringen ind allerede før 1100tallet: det anslås at pengerenter dominerede så tidligt som i midten af det 12te århundrede. Med gentagne markeder, som nu regulært og konsekvent involverede de umiddelbare producenter, ser vi udviklingen af en ny tvangsmæssig relation artikuleret i varecirkulationen. Den afgørende forskel fra tuskhandlen er, at varen nu repræsenterer socialt merarbejde. Modsatningen mellem brugsvaerdi og vardi står ikke mere alene, men er blevet moment $i$ en større modsatning: Modsatningen mellem udbyttede og udbyttere. Denne modsætning opstår ikke formidlet af et kontinuum af enkle subsumtioner og er derfor historisk forudsætningen for kontinuummets realisering, som vi skal se.

Klassekampens modsætninger kan nemlig udmærket udtrykke sig direkte udenom markedet, hvad de udelukkende gjorde før markedet blev udviklet, og hvad de blev ved med at gøre under hele feudalismen. Men da markedet blev et moment i udbytningen, opstod der en ny manifestation af klassemodsætningerne.

Modsætningen mellem merarbejdets, isoleret set, frie cirkulation og dets, samfundsmæssigt set, tvangsmæssige tilegnelse, udtrykte en ufri samfundsmassiggфrelse af de sociale relationer der blev artikuleret på markedet. Samfundsmæssiggørelsen måtte udtrykkes i en tilsvarende ufri manifestation. Den enkle subsumtion angår ikke produktionen og tilegnelsen, men er kun etableringen af arbejdsproduktets specifikke værdiform, cirkulationsform. Derfor kunne den enkelte enkle subsumtion ikke udtrykke den tvang, den nu gav bevægelse for, blev et moment i.

Kontinuummet som sådan måtte udtrykke denne tvang, og således realisere sig selv som kontinuum. I denne situation udgjorde pengevaren det tingslige udtryk for den sociale sammenhæng. Guldfetichen var dog ikke et tilstrækkeligt udtryk for dette, da den sociale sammenhæng var klassernes kamp om det sociale merarbejde, som cirkulerede alment tilgængeligt, set ud fra vareformen alene. Det sociale merarbejdes vareform måtte fordobles dels i varmeformen, der altså muliggjorde merarbejdets cirkulation, og dels i en social struktur, der kunne udtrykke den ufri samfundsmæssiggørelse igennem en fetich, og som reelt kunne opretholde den merarbejde-tilegnede klasses privilegium, selv i en situation, hvor merarbejdet blev sendt på markedet af bøndere uden øremærkning.

Det er helt afgørende for forståelsen af den feudale kongestats opståelse, at man er klar over, at denne udvikling var et resultat af den feudale klassekamp og dens basis i feudalismens $\varnothing$ kologisk-produktive basis. Og ikke omvendt, at 
den feudale handel, som varecirkulation, besad nogen form for "formspecificerende potens" eller historisk "subjektivitet", der kunne forandre det omliggende samfund, men at handelen netop kunne udvikle sig, fordi den hele tiden var integreret i feudalismens klassekamp.

Der var altså tale om en historisk mulighed for, at et kontinuum af enkle subsumtioner kunne udvikle sig, der kunne bringe udbytningen op på et højere niveau, ved at udnytte forandringerne i den tidlige feudalismes $\emptyset$ kologisk-produktive basis og udviklingen af arbejdsdelingen. Derfor blev denne mulighed grebet der, hvor 1) den tidligere europæiske feudalisme besad et ekspansivt potentiale i landbrugets udvikling; og 2) en historisk overleveret betingelse for udvikling af en højere social organisering end gods-landsby samfundet. ${ }^{26}$ Udgangspunktet for udviklingen af kontinuummet lå altså udenfor den lille samfundsmæssiggørelse, den tidlige feudale tuskhandel udtrykte.

For at muligheden skulle blive realitet, måtte kontinuummet udvikle en historisk konkret manifestation; uden en historisk konkret manifestation havde kontinuummet ingen historisk realitet. Dette blev klart vist i alle de fejlslagne fors $\varnothing \mathrm{g}$ på at udvikle pengeformidlet cirkulation uden garanti i kongemagten. Pengene kunne ikke stå alene. Denne historisk konkrete manifestation var ikke tilstede i den lille diskontinuerlige samfundsmæssighed tuskhandlen udtrykte. Den ufri og feticherede samfundsmæssighed pengecirkulationen udtrykte kunne ikke eksistere i sig selv, dvs. alene ved pengenes fetich, da de kun udtrykte den enkle subsumtions lille samfundsmæssighed taget enkeltvis (pr. varebytte), og ikke de historiske betingelser for den enkle subsumtions kontinuum, der nu var den tvangsmæssige repetition og klassekampsbestemte afhændelse af det sociale merarbejde til kirken, adlen og kongen.

Det tidlige feudale samfund besad i kongemagten en konkret manifestation af social sammenhæng. Denne sammenhæng havde ganske vist ikke noget med varecirkulationen at gøre, men var en manifestation af det feudale klassesamfunds hieraki. Den var det ideologisk-politiske fixpunkt for en udbytterklasse, der sikrede sin position ved en direkte politisk-ideologisk vold overfor bønderne. Dette samfund, der ikke kendte anden samfundsmæssig sammenhæng end den hellige hierakiske troskab og fromme underkastelse, kunne derfor ikke etablere andre relationer end dem der gjaldt indenfor godset, landsbyen og klosteret. Forholdet mellem adlen og kongen var derfor en reflektion af forholdet mellem adlen og bønderne. Ikke for ingen ting blev

26. Vi benytter her lejligheden og henviser til P. Anderson: Passages from Antiquity to Feudalism, NLB, 1974, samt Lineages of the Absolutist State, NLB, 1974, der tilsammen udgør en imponerende, syntetisk fremstilling af Europas (Verdens) udvikling fra antikken og frem til kapitalismens gry. 
Wilhelm Erobrerens vigtigste vassaller kaldt for tenants in chief, præcis som fæstebønderne var tenants.

Med kommuteringen af hoveriarbejdet bliver tilegnelsen af merarbejdet formidlet af pengene i form af afgiftsbetalinger. ${ }^{27}$ Dette bet $\varnothing \mathrm{d}$ en tilsvarende forvandling af adlens indbyrdes relationer, både mellem ridderne og baronerne, og mellem baronerne og kongen. Osse deres ydelser blev kommuterede og pengeformidlede. Vi må formode, at en af forudsætningerne for kommuteringen må have været, at den indebar en samtidig forvandling af relationerne mellem adel og bonde og adel og konge: for at kongen kunne få et direkte forhold til bønderne, dvs. til det sociale merarbejdes udspring, måtte de hierakiske relationer nedefter bringes på fællesnævner, og det skete netop med skyldigheder opgjort i penge. Samtidig må forvandlingen af det sociale merarbejdes cirkulationsform være resultatet af en bred social udvikling, hvor alle kunne se visse aspekter af forvandlingen, som forbedringer af deres egen situation. Når dette var muligt, kan det kun skyldes, at forvandlingen var muliggjort af, og resulterede i, en objektiv udvidelse af feudalismens produktive basis. ${ }^{28}$ Der har ikke været tale om en ren tvangsmæssigt gennemført forvandling. Befolkningens kraftige vækst fra ca. 800 til ca. 1300 tyder osse i den retning.

Muligheden for kontinuummet blev realiseret ved, at kongemagten udviklede en samfundsmæssig fetich, der tilsvarede kontinuummets tvang. Denne udvikling kalder vi kongemagtens komplexe subsumtion under de enkle subsumtioners kontinuum.

I den historiske udvikling af varecirkulationen og feudalismens $\emptyset$ kologiskproduktive basis er der altså to fundamentale diskontinuiteter. Dels den enkle subsumtion som giver bevægelse for arbejdets samfundsmæssige bestemmelse (eller i varebyttet giver det umiddelbare arbejde en samfundsmæssig bestemmelse). Det er den lille modsætning mellem vareformens to aspekter: værdi og brugsværdi. Her er den sociale artikulation af en del af det sociale

27. I England sætter kommuteringen ind i det 12te århundrede, går tilbage i det 13ende århundrede og atter frem i de følgende to århundreder. I Frankrig hang kommuteringen i mindre grad sammen med bøndernes oprør, men købtes ofte af hele områder. I Italien og Spanien var kommuteringens kronologi, - som den feudale udvikling i det hele taget, - mere regional. I Tyskland mistede arbejdsrenter betydning i det 13 ende århundrede. Efter 1450 var arbejdsrenter uden betydning i Vesteuropa.

28. Største kompetance på dette område er G. Duby. Grundig, omfattende, men også let overskuelig er hans Rural Economy and Country Life in the Medieval Europe, London, 1968 (1962), som tillige indeholder et betydeligt kildemateriale; mere fortællende er hans The Early Growth of the European Economy, London, 1974 (1973), som giver en god oversigt over feudalismens tidligste periode. Bl.a. L. Whiteś fors $\emptyset \mathrm{g}$ på at tilbagedatere den afgørende diskontinuitet i udviklingen af det feudale Europas landbrugsproduktion, antagelser vi selv ukritisk har overtaget i Historievidenskab nr. 10-11, s. 11-14, er tilbagevist først og fremmest af Duby, Hilton og Sawyer. Se vores revideringer i Feudalismens Rødder, RUC, 1978, s. 49-77, s. 111-115. Specielt om England er M. M. Postan: The Medieval Economy and Society, London, 1972, særdeles anbefalelsesværdi, men heller ikke uden gisninger på frihjul. 
merarbejde fri og tilfældig. Det er denne situation Engels beskriver i sit efterskrift til Kapitalen ${ }^{29}$ som varebyttet mellem de "kommunistiske urfællesskaber".

Dels den komplexe subsumtion, som er den afgørende diskontinuitet i feudalismens udvikling. (Ca. anden halvdel af det 12. århundrede i lande som England, Frankrig, Castillien og Sicilien). Her sker der nemlig det, at den frie artikulation af arbejdets samfundsmæssige bestemmelse, som det er givet ved den enkle subsumtion, overlejres af den dominerende modsætning i det historiske miljø, udbytningen i det feudale klassesamfund: arbejdets frugter cirkulerer ikke kun, de tilegnes osse. Tilegnelsen er ikke fri, men klassebestemt, på basis af udbytning. Derfor må pengenes frie bestemmelse overlejres af udbytningens bestemmelse, og det sker igennem den komplexe subsumtion af den feudale kongemagt. Vi kan sige, at her perverteres den sociale kraft, der ligger i kontinuum 1 (de enkle subsumtioners kontinuum, til forskel fra kontinuum 2, branchernes kontinuum, som vi skal udvikle nedenfor), og klassesamfundet udnytter den begyndende arbejdsdeling og produktivitetsstigning til for$\varnothing$ gelse af udbytningen. ${ }^{30}$ Kongemagtens komplexe subsumtion muliggjorde præcis den samme overgang fra indre modsætning til ydre modsætning, som muligg øres af varebytternes værdiudtryk. Vi skal nu fors $\emptyset g e$ at have vareanalysens bestemmelser i baghovedet. Pengevaren er en dobbeltform: den er dels brugsværdi, guldstof, og dels værdi, et produkt af samfundsmæssigt arbejde. Rugbrødet er en dobbeltform: det er dels brugsværdi, rugbrød, og dels værdi, et produkt af samfundsmæssigt arbejde. Disse respektive indre modsætninger i guldet og rugbrødet, udtrykkes og har historisk eksistens ved at pengevaren byttes mod rugbrødet, værdien udtrykkes i guldets materiale - det er bytteværdiens selvstændiggjorte udtryk - og brugsværdien isoleres i rugbrødet som guldets relative værdiform. De respektive indre modsætninger eksisterer som en ydre modsætning mellem to helt konkrete varer, guld og rugbrød. Overgangen fra de respektive indre modsætninger er resultatet af den enkle subsumtion.

Historisk skaber forhold uden for byttet modsætningen mellem brugsværdi og bytteværdi. De enkle subsumtioner giver disse omliggende modsætninger bevægelse. Vi forklarede, hvordan disse modsætninger udviklede sig til et kon-

29. Marx, Das Kapital, MEW 25, s. 906.

30. Om kongestatens opståelse se: Statens Historie, del 1, s. 29-34 og s. 142-187 og 218-257; Historievidenskab nr. 10-11, s. 19-34; Statens Historie, del 2, s. 1-13. Det er ikke noget velbeskrevet område. Udover to velskrevede artikler i henholdsvis The Cambridge Economic History of Europe, Vol 3, og The Fontana Economic History of Europe, vol 1, vil vi nævne to mindre kendte bøger: F. A. F. von der Heydte: Die Geburtsstunde des Souveränen Staates, Regensbrug, 1952. En eminent fremstilling af overgangen fra feudal kongemagt til feudal kongestat. E. Kantorowicz: The Kings two Bodies. A Study in Medieval Political Theology, Princeton, 1957, der behandler kongestatens dialektik mellem person og stat; en fin perspektivering af enhver statsteori. 
tinuum. Disse nye modsætninger fik da historisk bevægelse igennem den komplexe subsumtion af den feudale kongemagt. Den komplexe subsumtion har de samme betingelser som den enkle subsumtion, og vi skal ved analogi fors $\varnothing$ ge at skematisere den komplexe subsumtion af den feudale kongemagt.

Den historiske udvikling havde, som sagt, skabt en samfundsmæssig sammenhæng, der blev udtrykt i pengene. Guldet var en fetich for de umiddelbare producenters sammenhæng igennem handlen. Mønterne kunne dog ikke alene fungere som en fetich: de skulle præges, de skulle bakkes op af en magt, der kunne garantere, at de blev respekteret som en fetich for samfundsmæssigheden. De enkle subsumtioners kontinuum subsumerede kongemagten, og den feudale kongestat blev udviklet som fordobling af pengeformen. Den fordobling Marx taler om i Grundrisse, skyldes altså den historiske samtidighed af to strukturer, dels arbejdets samfundsmæssighed - modsætningen mellem værdi og brugsværdi - og dels modsætningen mellem udbyttede og udbyttere. Staten/pengene forholder sig således til klassekampsam/fundsmæssigt arbejde.

Kongestaten skal vi derfor placere på guldets plads i vores analogi. Hvad er så kongestatens "brugsværdi" og "værdi"?

Dens "brugsværdi" er den feudale kongemagt. Den feudale kongemagt var et direkte udtryk for det feudale samfunds sammenhæng og dette aspekt fortsatte den feudale kongestat at have.

Den feudale kongestats "værdi" er dens manifestation af pengecirkulationen. Men denne "værdi" kan ikke eksistere som "værdi", men kun som "bytteværdi", dvs. at den feudale kongestat må stå i et "værdiforhold" til en anden instans, der er placeret analogt med rugbrødet. Hvad er det for en instans?

Det kan vi ikke svare på ud fra en isoleret betragtning over pengecirkulationen. Kun ved at overveje hvilken konkret historisk omstændighed, der ledte til de enkelte subsumtioners kontinuum, bliver vi i stand til at opklare dette problem. De historiske omstændigheder var den feudale klassekamp, dvs. den specifikke måde hvorpå det sociale merarbejde blev produceret, fordelt og tilegnet på under feudalismen. Udviklingen af kontinuummet var en historisk konsekvens af, at bøndernes skyldigheder nu blev til betalinger. Den enkelte bonde stod overfor pengene som mønter, men alle bønderne stod overfor "alle pengene" forstået som pengenes fetich for den samfundsmæssighed kontinuummet udtrykte.

Imellem pengefetichen og bønderne var der altså, foruden modsætningen mellem det private umiddelbare arbejde og den samfundsmæssige udveksling, modsætningen mellem udbyttede og udbyttere. Pengene var derfor en fetich for en $u f r i$ samfundsmæssighed og kongestaten tilsvarende manifestation for en ufri samfundsmæssighed. Det der derfor udfylder rugbrødets plads 
i vores anaogi er bondeklassen. Mellem den feudale kongestat og bønderne var der altså en dobbelt relation: dels enkelvis som sælgere af landbrugsprodukter hhv. udsteder af mønter og samfundsmæssigt set mellem udbyttede og udbyttere.

Fortsætter vi analogien, ser vi, at bondeklassen på samme vis som den feudale kongestat har en "værdi" og en "brugsværdi". Dens "brugsværdi" er dens position som umiddelbar producent. Dens "værdi" er mere kompliceret, da der mellem bønderne, kun i undtagelsestilfælde, kunne være tale om en egentlig samfundsmæssig sammenhæng. Disse undtagelser var bondeoprørerne. I de store klassekampe samledes bønderne og realiserede sig som klasse. ${ }^{31}$ Men deres fundamentale svaghed var at samlingen altid var negativ, vendt mod udbytterklassen - der var ikke noget positivt autonomt samlingspunkt.

Vi finder dette meget tankevækkende, da det viser hvordan feudalismens overfladiske samfundsmæssighed manifestererede sig i, at bønderne ikke kunne kæmpe for et bondesamfund uden klasser. I alle deres paroler gik det igen, at de altid ville beholde kongen. Kongen som netop var feudalismens konkrete manifestation af en ufri og klassedelt samfundsmæssig sammenhæng. Og som altid på det mest grusomme faldt bønderne i ryggen, hvis det var nødvendigt, eller bare huggede dem ned. Arbejdet var ikke samfundsmæssigt, og derfor var bøndernes anti-stat ikke i stand til at transkendere det feudale klassesamfund. Og derfor måtte bøndernes sønner og døtre mange generationer senere lide og kæmpe som lønarbejdere. Først med lønarbejdet opstår der historisk mulighed for en positiv autonom samfundsmæssig sammenhæng blandt de udbyttede.

\section{B. Fra kontinuum 1 til kontinuum 2}

Her giver vi en ultra-kort redegørelse for udviklingen i de $\varnothing$ konomiske former frem til kapitalen. Vi antyder hvor linjerne om staten og verdensmarkedet ender idag, i sidste afsnit af artiklen.

31. Se hertil Statens Historie, del 1, s. 187-218; del 2, s. 160-175. Til feudalismens bondeoprør skal vi her kun nævne de bedste fremstillinger: R. Hilton: Bond Men Made Free. Medieval Peasent Movements and the English Rising of 1381; dens indledning giver en af de bedste introduktioner overhovedet til feudalismen. M. Mollat and P. Wolff: The Popular Revolutions of the Late Middle Ages, London, 1973; H. Fagan: The Unsheated Sword, Episodes in English History, Part I, the Commoners of England, London, 1958; helt enestående er N. Cohn: The Pursuit of the Millenium. Revolutionary Millenarians and Mystical Anarchists of the Middle Ages, New York, 1974, der er begrænset til Nordvesteuropa, men som til gengæld rækker betydelig udover den traditionelle opfattelse af de undertryktes kamp under feudalismen. En grusom, men også dybt opmuntrende bog. Endelig skal til slut nævnes M. Beer: Allgemeine Gesichte des Sozialismus und der Sozialen Kämpfe, PolitladenReprint, 1971 (1931). 
Kontinuum 2 vil vi nedenfor udvikle analogt med kontinuum 1, dets enkelte momenter er ikke de enkle subsumtioner - varebytterne - men de reelle subsumtioner - brancherne, dvs. virkeliggørelsen af merværdien i markedsværdien og profitraten. Historisk udvikles kontinuum 2 først i England igennem en lang og kompliceret proces der strækker sig fra ca. 1600 til ca. 1800, med revolutionen i 1640 som det politiske vendepunkt. ${ }^{32}$

Den feudale kongestat udvikler sig til den absolutistiske kongestat og med den Engelske Revolution (og andre borgerlige revolutioner) afskaffes kongestaten. En merkantil borgerlig stat opstår. Kontinuum 2 udvikler sig først med den industrielle revolution, først da virkeligg ør merværdiproduktionen sig som samfundsmæssigt herskende princip igennem den samfundsmæssige gennemsnitsprofitrate. På dette punkt virkeligg ør kontinuummet sig igennem en komplex subsumtion af den borgerlige merkantile stat og den borgerlige industrielle stat opstår (eller hvad vi nu skal kalde den). Først med denne historiske bevægelse kan man sige at kapitalismen har sat sig igennem indenfor en given national ramme. I England sker dette mellem 1780 og 1830. I alle andre lande senere. Dvs. at i en periode fra 1640 til 1780 er sammenhængen mellem udbytning og undertrykkelse prækær og kun givet ved staten, som den er defineret af verdensmarkedet. Dette skyldes simpelthen, at den feudale sammenhæng mellem undertrykkelse og udbytning fik knækket ryggen og halsen skåret over i Revolutionen. Men på den anden side har den kapitalistiske sammenhæng endnu ikke udviklet sin egentlige virkelighed, fordi kontinuum 2 ikke er udviklet. Staten er borgerlig fordi den ikke er feudal, og den er merkantilistisk fordi den ikke er kapitalistisk: landbrugsproduktionen er endnu alt overskyggende, merarbejdet tilegnes som arbejde for løn og ikke som mervardiproducerende lønarbejde. Der er kun få afsnit af den materielle produktion, der er udviklet som brancher. Altså er det borgerne, der tilegner sig merarbejdet, ikke de feudale monopolister osv. Men de gør det kun undtagelsesvis som kapitalister. Staten er merkantilistisk, fordi dens relation til andre nationer ikke var borgerlig, verdensmarkedet muliggjorde stadig feudale handelskapitalistiske metoder, især i Indien for Englands vedkommende. Med den Amerikanske Revolution oprettes de første internationale relationer mellem to nationer der ikke er feudale, mellem to borgerlige stater. Dette følges hurtigt op af folkeretslige internationale traktater osv. I dette dilemma eksisterede den merkantile borgerlige stat, men da borgerskabet

32. Vi skal ikke her tage hele overgangsproblemet op. F.ex. kræver dette en diskussion af et marxistisk begreb for den feudale produktionsmåde, hvilket er forbigået i denne artikel. En forholdsvis detaljeret fremstilling af de konkrete begivenheder i England og et fors $\emptyset \mathrm{g}$ på at forklare dem, kan man finde $\mathrm{i}$ Statens Historie, del 2, s. 14-194. I såvel del 1 som del 2 er der i Øvrigt omfattende og kommenterede litteraturlister. 
havde taget magten fra feudalismens konge behøvede kontinuum 2's komplexe subsumtion af denne stat ikke antage voldsomme former. ${ }^{33}$

Nationen er en feudal enhed, den borgerlige stat er som nationalstat kapitalismens udvikling indenfor feudale rammer. Verdensmarkedet er derfor en kamp for at kapitalismens mindste virkelighed, branchen, bryder ud af nationen og etablerer sig som en international branche vendt mod national-staten. Kapitalismen har først sat sig igennem fuldkomment, når nationerne er væk, for de er den sidste rest af feudalismen. (Dette uddybes i afslutningen).

\section{AFSNITTET OM KAPITAL}

\section{A. Kapitalismens mindste virkelighed - branchen}

\section{Introduktion}

I dette afsnit skal vi forsøge at klarlægge kapitalismens præcise udspring. Vores arbejde er koncentreret om at bestemme kapitalismens mindste virkelighed, dvs. det mindste moment hvori kapitalismen kan virkeliggøre sig, have historisk eksistens. Dette moment er både kapitalismens historiske udgangspunkt og det moment hvorigennem den reproducerer sig på en stadig større skala. Kapitalismens essens er mervaerdiproduktion, dvs. udbytning af lønarbejdere igennem kapitalistisk vareproduktion. Vi vil ikke argumentere for merværdiproduktionen som kapitalismens essens, men forudsætte enighed på dette punkt. $^{34}$

Vores kurs er bestemt af det lille skema over den kapitalistiske produktionsproces:

P - V $\left\{\begin{array}{l}\text { arbejdskraft, } \\ \text { produktionsmidler, } \\ \text { ravarer }\end{array}\right\}$.. produktionsproces .. P' - V'

33. Dette tillige med USA's historie og verdensmarkedets udvikling i århundredet 1750-1850 er emnet for en tredie rapport, som forventes færdig i foråret 1979 under titlen Statens Historie, del 3.

34. Der er måske enighed med dem der læser dette, men ikke i den marxistiske diskussion i almindelighed. I den tyske diskussion understreger man nok dette punkt, men forholder sig tøvende overfor en historisk specifisering. Heide Gerstenberger er en opmuntrende undtagelse; hendes analyse diskuteres i Statens Historie, del 1, s. 293-310. I den hjemlige debat har man været fixeret af den danske modificerede, og i England, USA og Frankrig opererer man ikke med et dialektisk kapitalbegreb. Se f.ex. en informativ artikel som Aidan Foster Carter: The Modes of Production controversy, New Left Review, 1977. 
hvor P er den udlagte kapital (kapital som penge), der vender tilbage forstørret som $\mathrm{P}^{\prime}=\mathrm{P}+$ merværdien. $\mathrm{V}$ er de indkøbte varer (kapitalen som produktiv kapital) der består af arbejdskraft (variabel kapital), råvarer (flydende konstant kapital) og produktionsmidler (fast konstant kapital). Ud af deres produktive konsum kommer en forstørret varemasse V' (kapitalen som varer) der endelig realiseres i P' der indeholder merværdien.

Først ser vi på den indledende cirkulationsakt $\mathrm{P}$ - V; den foregår indenfor den simple varecirkulations bestemmelser. Produktionsprocessen er konkret arbejde, den umiddelbare produktionsproces' bestemmelser er ikke overskredet. Men ved den anden cirkulationsakt V' - P', ændres hele billedet pludseligt: nu skal merværdien realiseres, det simple varebyttes bestemmelser overlejres af den kapitalistiske varecirkulations bestemmelser. Varebyttet bliver til konkurrence. Hermed sker der et tilsyneladende sammenbrud i værdibegrebernes relevans for den virkelige historie. En simpel kvantitativ argumentation om overgangen fra produktion til cirkulation løber ind i uoverstigelige selvmodsigelser.

Marx tænder den røde lygte på s. 162 i tredie bind af Das Kapital: "Det synes altså, som om værditeorien er uforenelig med produktionens faktiske fremtrædelser, og derfor fuldstændig må give afkald på at forstå den.” Nej, selvfølgelig giver Marx ikke afkald på at forstå den kapitalistiske produktion, tværtimod overskrider han den indskrænkede logik der ledte frem til modsigelsen. Dette skal vi komme nærmere ind på nedenfor. For at komme videre i argumentationen må Marx overskride en kvantitativ logik og specificere sin fremstillings begreber dialektisk, dvs. gøre totaliteten konkret i en tankemæssig rekonstruktion af den subsumtion der på dette punkt i den virkelige historie opretter en ny bevægelsesform for modsætningen mellem værdi og brugsværdi.

Hans dialektiske overgang eller specificering består i en tankemæssig rekonstruktion af merværdiens forvandling til profitformen, af merværdiratens forvandling til profitraten; eller hvad der er det samme: at profitratens bevægelser er merværdiproduktionens virkeliggørelse. Den materielle bestemmelse Marx trækker ind fra højre i sin dialektiske overgang er branchen. Eller mere præcist: han viser hvordan et bestemt udsnit af den materielle produktion subsumeres under kapitalen og kapitalen opretter igennem denne subsumtionsbevægelse sin bevægelsesform branchen. Branchen er således kapitalismens mindste virkelighed og momentet i dens reproduktion. Vi vil kalde denne subsumtion for den reelle subsumtion.

Inden vi udvikler den reelle subsumtion i detalje er vi nødt til at gøre op med to fundamentale misforståelser: at hhv. lønarbejde før branchen skulle være kapitalisme, og profit af kapital før branchen skulle være kapitalisme. Marx forfalder selv flere steder til en identifikation af kapitalisme med disse to forhold. 


\section{2) "Lфnarbejdet" før kapitalismen}

Momenterne i kontinuum 1 er som omtalt, de mange enkle subsumtioner der etablerer vareformen. Hver enkelt subsumtion er konkret og defineret i forhold til en brugsværdi. Brugsværdien og værdiens modsætning er kun til i konkrete forhold mellem ting som æbler og sølvræve, rugbrød og guld.

Marx skriver: "Vi har tidligere set, hvorledes varen (arbejdskraften) må få en dobbelt eksistensmåde for at være fremstillet på passende måde for cirkulationen. Den må ikke kun træde overfor køberen som en artikel med bestemte nyttige egenskaber, som en bestemt brugsvardi, der kan tilfredsstille bestemte behov, hvad enten disse tilhører den individuelle konsumption eller den produktive konsumption. Dens bytteværdi må have opnået en form der, skønt den er ideel, må være forskellig fra, distinkt og selvstændig i forhold til dens brugsværdi og bytteværdi. Den må fremtraede som enheden af brugsværdi og bytteværdi, men den må samtidig fremtrcede som fordoblet deri. I sin pris (lønnen) får dens bytteværdi denne selvstændige form, der helt igennem er uafhængig af dens brugsværdi, og som blot og bar tilstedeværelse af den materialiserede arbejdstid (ved arbejdskraften formidlet igennem det individuelle konsum ${ }^{35}$ ) thi prisen er det udtryk, hvori bytteværdien er udtrykt som bytteværdi, dvs. er udtrykt som penge, og således som sådan er den ganske vist udtrykt i regnepenge (til forskel fra penge som cirkulationsmiddel, dvs. de håndgribelige beviser på pengevaren)." ${ }^{36}$

Pointen er her at der kun findes én vareform, men mange subsumerede brugsværdier. Set ud fra kontinuum 1's synsvinkel gælder de som lige børn i legen, når de bare etablerer et værdiforhold til en anden vare (pengevaren). Det er indlysende at dette er et afgørende argument, for det betyder at arbejdskraftens vareform artikuleret indenfor kontinuиm 1's rammer er totalt kongruente med de andre varer, og således på ingen måde $i$ sig selv, som udtryk for varesamfundets daværende udvikling og omfang, kunne henvise til den senere kapitalisme (kapitalistisk merværdiproduktion). Der skulle være argumenteret tilstrækkeligt for en kongruens mellem disse to varer (varen arbejdskraft og pengevaren og dermed alle varer) hvad angår selve subsumtionen $i$ varebyttet, noget ganske andet er så hvad der bringer de forskellige varer på markedet. ${ }^{37}$

Man kan ikke forstå "lønarbejdet" ud fra lønnen, dvs. arbejdskraftens vareform. Det kan man se i den megen snak om "tidlig-kapitalisme", bl.a. hos

35. Arbejdskraftens værdi er dog langt mere kompliceret og sammensat. Se vores antydninger i næste afsnit.

36. Marx: Resultater af den umiddelbare produktionsproces, Modtryk, s. 145 (Vores tilføjelser).

37. Om det tidlig lønarbejde se Statens Historie, del 1, s. 86-100; del 2, s. 33-41 og 97-128. 
Marx, i de italienske bystater osv. der bygger på en manglende distinktion mellem lønarbejde og arbejde for løn, hvor prisen på arbejdet i det andet tilfælde ikke stod i nogen direkte forhold til arbejdskraftens værdi, hvor distinktionen mellem arbejdskraft og arbejde var flydende, fordi lønnen ikke var et forvandlet prisudtryk for den variable kapitaldel i en produktionsproces. Når handelskapitalen mængede sig med den umiddelbare produktionsproces var det ganske vist fra handelskapitalens synsvinkel penge udlagt som kapital, men profitten kom ikke fra produktionsprocessen, men fra det dyrere salg. Fra produktionsprocessen's synsvinkel forvandledes "kapitalen" til penge der blev byttet for de producerede varer. Handelskapitalen ophører med at være kapital i produktionsprocessen og bliver til penge. Da der således ingen kapital var, måtte prisen på arbejdskraften forholde sig rent udvendigt til arbejdskraftens værdi, og derfor tendere mod at være en pris på arbejdets frugter istedet for på arbejdskraften. I utallige tilfælde var lønnen ikke pr. tid, men pr. arbejdsprodukt. Her blev der tilegnet ubetalt arbejde i det omfang arbejdsproduktet blev solgt under sin værdi af den umiddelbare producent (som ejede produktionsmidlerne), hvad der var meget almindeligt, men ikke produceret mervardi. Se hertil Marx' distinktion mellem ubetalt arbejde og værdisættende arbejde. ${ }^{38}$

Altså: arbejdskraftens vareform, udtrykt i lønnen, blev, når arbejderen først faldbød sin arbejdsevne på "arbejdskraftmarkedet", oprettet igennem eksakt den samme subsumtion som alle andre vareformer i kontinuum 1. Dens kongruens med de andre vareformer i kontinuum 1, gjorde at den måtte forholde sig som de andre varers besiddere til pengevaren. Dvs. at besidderen af arbejdskraftvaren var underlagt de samme restriktioner, som besidderne af de andre varer. Disse restriktioner lå ikke så meget på tvangen til at sælge sin egen arbejdskraft og ellers holde kæft, men tværtimod at man godt kunne regne med at blive snydt i selve bytteprocessen, og at man ikke skulle gøre vrøvl over det. Lønnen var ikke ækvivalent med arbejdskraftens reproduktionsomkostninger, men lå langt under. Derfor var ham der arbejdede for løn ikke fri i kapitalistisk forstand (fri fra produktionsmidler, fri til at vælge udbytter og med et borgerligt krav, som varebesidder, på ækvivalentbyttets opretholdelse). Han blev ikke udbyttet af en kapital igennem merværdiproduktion, men snydt af handelskapitalen i cirkulationsprocessen. Det er indlysende at dette ikke ville være muligt at opretholde som moment i den feudale udbytning, hvis ikke pengeformen var fordoblet i pengeform og kongestat.

Udviklingen fra arbejde for løn til lønarbejde, kan ikke forståes ud fra kontinuum 1, vareformen og lønnen, men kun ud fra det feudale klassesamfunds rea-

38. Marx: Das Kapital III MEW 25, s. 311; Theories of Surplus Value I. 
litet, der omgav kontinuum 1. Og dog var netop kongruensen mellem arbejdet for løn og lønarbejdet, set ud fra lønnen, fra vareformen, en af forudsætningerne for at det feudale klassesamfund blev overskredet af det kapitalistiske klassesamfund, hvor varen arbejdskraft fik en helt ny betydning. Vi ser således en vigtig ting: i samme omfang som lønarbejdet under kapitalismen reproducerer sin egen undertrykkelse ved salget af arbejdskraften til kapitalisten, og således er fri i cirkulationen, i samme omfang er den person der arbejder for løn under feudalismen fri i produktionen, men undertrykt i cirkulationen af kongestaten: her er det altså ikke udbytningen der skaber undertrykkelsen, men undertrykkelsen der skaber udbytningen.

For os er det afgørende, at man således kan forklare hvordan lønarbejdet kunne opstå, som arbejde for løn, fuldsteendig indenfor den feudale samfundsformations rammer, samtidig med at det var begyndelsen på dannelsen af det andet kontinuum, der sprængte den sammenhæng mellem $\emptyset$ kologisk-produktiv basis og udbytning og undertrykkelse, der var etableret med udviklingen af kongestaterne. Med den gradvise forvandling af arbejdet for løn til egentligt lønarbejde, kommer modsætningen mellem de to kontinuummer osse til at bryde $l \varnothing$ s i statsligt regi.

\section{3. "Kapital"-profit før kapitalismen}

Vi nåede frem til at det tidligste lønarbejde mere korrekt må opfattes som arbejde for løn, og at denne løn ikke er en kapitals variable del: der er altså arbejde for løn, men ingen merværdiproduktion.

Lønformen er en nødvendig, men ikke tilstrækkelig bestemmelse ved merværdiproduktionen. På den anden side må vi gå ud fra at der blev udpresset et vist merarbejde af dem der var tvunget til at arbejde for løn. Med andre ord: de kunne være kilden til profit. Men hvad ligger der så i profitformen?

Den historiske udvikling af pengeformernes forvandlinger i kontinuum 1 var bundet til handelskapitalens og ågerkapitalens udvikling. Altså to kapitalformer der har det fælles karakteristikum, ikke at hente deres profit igennem merværdiproduktion, men ved brud på ækvivalentbyttet. Deres profitformer kunne i bestemte forhold springe mange af den industrielle kapitals mindre avancerede former over, og gå direkte mod de mest udviklede, såsom kapitalrente i modsætning til driftsherregevinst, aktieselskaber i modsætning til familieeje osv. Med udviklingen af et aktiemarked på børsen i Amsterdam i det 17. århundrede og lidt senere i London, og et marked for statsgældspapirer osv. blev der udviklet en profitform, der nok kunne opfatte profitten som et konkurrencebestemt (samfundsbestemt) tillæg til den udlagte pengesum, men som på den anden 
side overhovedet ikke havde nogen anelse om hvor denne profit stammede fra. Det var først med opløsningen af den absolutistiske merkantilisme i den borgerlig merkantilistiske stat, at arbejdet begynder at blive opfattet som værdiens kilde. ${ }^{39}$

Åger - og handelskapitalens profitters reale basis var nok arbejdet, men den specifikke sammenhæng mellem udbytning og undertrykkelse der herskede i den feudale samfundsformation, formidlet af kongestaten, gjorde profitternes sammenhæng med arbejdet helt vilkårlig.

Der var en fundamentalt forskellig baggrund for de profitformer der optrådte $\mathrm{i}$ forbindelse med kontinuum 1 og 2 . Det betød igen en helt særegen sammenhæng mellem de uudviklede og embryonale profitformer der stammede fra produktionsprocesser hvor folk arbejdede for løn, og på den anden side de handels- og ågerprofitter der blev trukket ud af cirkulationen igennem obstruktionen af ækvivalehtbyttet. Handels- og ågerprofitterne forblev nemlig den dominerende form. Denne dominans blev opretholdt igennem statens regulering af cirkulationen. Dominansen betød at det merarbejde der blev presset ud af dem der arbejdede for løn, kun i et mikroskopisk omfang blev tilegnet af den givne mester eller jordejer, mens hovedparten blev tilegnet af de næste led i varecirkulationen. ${ }^{40}$ Yderligere kan man se hvordan den eneste måde hvorpå de umiddelbare udpressere kunne få del i deres eget rov, var ved at efterligne handelskapitalens organisering, dvs. være i overensstemmelse med den feudale sammenhæng mellem udbytning og undertrykkelse, og danne deres egne monopoler, laug og handelsforeninger. Et eksempel er The Clothworkers Corporation i London, der fuldstændigt blev underordnet monopolhandlens liglugt. De måtte organisere sig som andre laug, med det formål at obstruere ækvivalentbyttet, hvad der samtidig var en permanent hæmsko for udviklingen af det kapitalistiske lønarbejde og dermed for deres egen produktivitet.

Resultatet blev at selv hvor handelskapitalen ikke direkte havde lagt sin klamme hånd over den umiddelbare produktionsproces, blev dens forhold til det umiddelbare arbejde efterlignet af de umiddelbare udpressere.

39. Se hertil Marx: Theories ..., I om Didley North, s. 364 og 368-372; H. Gerstenberger: Zur Theorie der Historischen Konstitution des Bürgerlichen Staates, Prokla 8/9, en meget anbefalelse sværdi artikel; D. C. Coleman: Revisions in Mercantilism, en fin indføring af forskellige debatører.

40. Dette dokumenteres klart af R. Grassby: English Merchant Capitalism in the late 17th cen. The Composition of Business Fortunes, Past and Present nr. 46; Om handelsinteressernes dominans over produktionen se endvidere B. Supple, Commercial Crisis and Change in England, 1600-1642. A Study in the Instability of a Mercantile Economy, Cambridge, 1970 (1959); C. Wilson: Englands Appren iceship, 1603-1763, Longmans Green, 1965; J. U. Nef: Industry and Government in France and England, 1540-1640, London 1969 (1940). 
Det betød at det var den konserverende og ikke den revolutionerende profitform, der dominerede. ${ }^{41}$ Dette var muligt fordi ingen af profitformerne på det tidspunkt havde rod i merværdiproduktionen (som ikke eksisterede), men kun i direkte afhændet arbejde. Denne direkte afhændelse var baseret på undertrykkelsen igennem kongestaten. De to profitformer, handels(åger-)kapitalens og forlagsvirksomhedens, hang kun sammen, var dele af den feudale produktionsmåde, igennem pengene, dvs. kongestaten. Profitformerne var kongruente i deres overfladiske forhold til produktionsprocessen, - men totalt inkongruente i deres potentielle udvikling. Vi ser her en analog kongruens mellem to momenter i de to kontinuumer, som slår om i direkte modsætning, når kontinuum 2 bliver udviklet. Disse kongruenser er det historiske udgangspunkt for etableringen af den kapitalistiske produktionsmåde "i skødet på den gamle".

Konsekvensen af dette er at det bliver meningsløst at diskutere om det tidlige arbejde for løn producerede merværdi. Merværdien er en kategori der forholder sig til den kapitalistiske produktionsproces. Det er stadig dens specifikation, selvom Marx rask væk taler om merværdi som synonym med merarbejde. Hvis enheden mellem umiddelbar produktionsproces og cirkulationsproces ikke er etableret som kapitalistisk produktionsproces, bortfalder diskussionen om merværdi. Vi skal i næste afsnit vise at den kapitalistiske produktionsproces kun kan komme til sig selv som brancher. Sammenhængen mellem den umiddelbare produktionsproces (hvor der altså i visse sektorer blev arbejdet for løn) og cirkulationsprocessen (hvor der altså blev akkumuleret kapital) var etableret igennem den specifikt feudale sammenhæng mellem undertrykkelse og udbytning. Resultatet var handelskapitalens dominans. Det betød en pervertering af den umiddelbare produktionsproces' profitform: dens sammenhæng med produktionsprocessens $\emptyset$ konomiske elementer blev aldrig udviklet, eller blev ophævet, så at sige ved kongeligt dekret.

Men, og det er den afgørende kvalifikation af ovenstående, så betød det faktum at visse udbyttere fik deres profit ved at lade folk arbejde for sig for løn, en potentiel mulighed for at overskride den handelskapitalistiske profitforms begrænsning. Det er derfor vi må fastholde at der eksisterede to fundamentalt forskellige profitformer, selvom de taget pr. moment var fuldstcendig kongruente. Hvis man overser dette er man tvunget ud i den uholdbare position, hvor man må forklare udviklingen af den industrielle kapital, som en liniær udvikling af handelskapitalens akkumulation. Og det er simpelthen ikke i overensstemmelse med de historiske fakta.

41. Se hertil Marx: Das Kapital III MEW 25, s. 347. Diskussionen af disse to profitformer er i $\emptyset$ vrigt central for Takahashi, Sweezy og Dobb i R. Hilton: The Transition . ., 1978. 


\section{Branchen}

\subsection{P - V (prod. proc., V' - P')}

Lønarbejdet som værdisættende arbejde, merværdiproduktionen, forudsætter mere end lønformen. Merværdiproduktionen forudsætter mere end kapital der afkaster profit i cirkulationen. Det punkt vi stadig vender tilbage til, er merværdiproduktionens, den kapitalistiske produktionsproces', krav om enheden af disse to momenter i kontinuum 1 (varen arbejdskraft og pengevarens forøgelse i cirkulationen) som to diskontinuiteter i den feudale produktionsmådes udvikling (arbejde for løn og samfundsmæssigt udlignede profitformer). Deres samtidige eksistens, og yderligere deres samtidige eksistens i et omfang der muliggør at denne enhed bliver sat som moment i et nyt kontinuum.

Den $\varnothing$ kologisk-produktive basis må have udviklet visse arbejdsprocesser til et punkt, hvor produktiviteten ikke er bundet af de naturgivne forhold: hvor visse afsnit af den materielle produktion kan indlede en kommulativ stigning af den tekniske sammensætning, der har tendens mod udligning af produktionsbetingelserne.

Cirkulationsprocessen må have udviklet en cirkulationsfrihed, der muliggør at ækvivalentbyttet tendentielt kan sætte sig igennem i varecirkulationen. Dvs. fjernelse af alle de feudale obstruktioner og udvikling af kapitalmobilitét i alle dens saglige bestanddele: varer (herunder arbejdskraften), produktionsmidler og penge. At denne udvikling dog modificeres af eet afgørende punkt, nationen, skyldes den borgerlige stats subsumtionshistorie. ${ }^{42}$

Det er en umiddelbar kendsgerning, at disse diskontiuiteter, der ser verdens lys på Englands grønne $\varnothing$, følges af den kapitalistiske produktionsmåde. Som vi nævnte det ovenfor, må forudsætningen for succes med den teoretiske rekonstruktion, være en korrekt specificering af "kapitalismen" som historisk fænomen. Derfor skal kapitalismen specificeres ud fra den mindste virkelighed, da det der dens opståelses- og reproduktionsmoment. Den mindste virkelighed skal fremstilles tankemæssigt som en rekonstruktion af den specifikke

42. Om udviklingen af den $\emptyset$ kologiske-produktive basis henviser vi til E. Kerridge: The Agricultural Revolution, London, 1967 og J. U. Nef: The Progress of Technology and the Growth of LargeScale Industry in Great Britain. 1540-1640, i Economic History Review, Vol 5 1934; til varehandelens udvikling nævner vi P. J. Bowden: The Wool Trade in Tudor and Stuart England, London, 1962 og R. Davis: English Foreign Trade, 1660-1700, Economic History Review, Vol), 1954. Om den absolutistiske stats monopolpolitik for industri, landbrug og handel og dens afskaffelse med revolutionen, se M. James: Social Problems and Policy during the Puritan Revolution, 1640-1660, London, 1930. Den bedste generelle indføring i perioden er C. Hill: Reformation to Industrial Revolution, Penguin, 1969 (1967). Kan suppleres med L. Stone: Causes of the English Revolution, 1529-1642, London, 1972. 
subsumtion, der opretter og reproducerer dette moment. Vi skal nu vise, at denne mindste virkelighed ikke er den kapitalistiske produktionsproces, $i$ "almenhed" osv., men, analogt med vareanalysens resultat, må være en relation mellem to umiddelbare kapitalistiske produktionsprocesser, dvs. enheden af umiddelbar produktionsproces og cirkulationsproces. Vi skal vise at denne enhed må opstå og reproduceres i en relation mellem brancher, både af logiske og historiske årsager. Vi vil, som sagt, kalde denne subsumtion for den reelle subsumtion, fordi Marx anvender denne betegnelse, ganske vist i en mere snæver betydning.

Som vi skrev ovenfor, er vores kurs bestemt af skemaet for den kapitalistiske produktionsproces. Vi skal nu gennemrejse denne artikulation af merværdiproduktionen, og skridt for skridt specificere den tankemæssige rekonstruktion ud fra branchens virkelige subsumtion.

Vi kan se at branchen (eller den umiddelbare produktionsproces, det er det samme på dette trin af argumentationen, branchen er bare mange umiddelbare produktionsprocesser ved siden af hinanden) som køber selv definerer brugsværdien, som krydsningspunktet mellem en specifik materialitet og det konkrete arbejdes behov. Dette behov formuleres af kapitalisten, som leder af arbejdet og indkøber af arbejdets saglige bestanddele. Råstoffer, maskiner, bygninger og arbejdskraft indkøbes. Vi har tidligere unders $\varnothing$ gt dette i forbindelse med arbejdskraften, hvor diskussionen af "kvalifikationer" blev sat i den sammenhæng. ${ }^{43}$ Alle varer der indgår i den umiddelbare produktionsproces byttes mod kapitalistens penge i et varebytte, hvor alle bestemmelserne i den enkle subsumtion er intakte, dvs. at alle bestemmelserne fra kontinuum 1 stadig er intakte og ikke overskredne. Det er vigtigt at holde sig dette for $\varnothing \mathrm{je}$, fordi det er den reelle korrelation mellem den virkelige historie og vores tankemæssige rekonstruktion af den. For kapitalisten adskiller hans $\mathrm{k} \emptyset \mathrm{b}$ sig ikke fra de $\mathrm{k} \emptyset \mathrm{b}$ der indgår i det individuelle konsum. Brugsværdien eksisterer kun som en konkret brugsværdi, der kan konsumeres i en ganske specifik sammenhæng, enten produktivt eller individuelt. For køberen af en vare, der skal have sine behov dækket, er varebyttet mellem hendes penge og sælgerens varer fuldstændig kongruent med den simple varecirkulations varebytte, selvom det foregår under nutidig kapitalisme. Ikke for ingenting lægger Marx ud med: "Ved første blik fremtræder den borgerlige rigdom som en uhyre samling varer, hvor den enkelte vare er dens elementar væsen." ${ }^{44}$ og otte år senere: "Samfundenes rigdom, i hvilken den kapitalistiske produktionsmåde hersker, fremtræder som "en uhyre samling varer", den 
enkelte vare som dens elementarform." ${ }^{45}$ Der indgår ikke flere bestemmelser i dette bytte set fra køberens synsvinkel.

For den snottede kapitalist er det faktisk ligegyldigt om de varer hans produktion kræver, er produceret på den ene eller anden måde, bare de kan bruges og har en rimelig pris - det simple varebyttes overvejelser. Set ud fra den samfundsmæssige arbejdsdelings synsvinkel er hans behov, efterspørgsel, kun et molekyle i det samfundsmæssige behov for disse brugsværdier. For ham er dette samfundsmæssige behov ligegyldigt. Kun i særlige situationer, hvor det bliver muligt at oprette former for monopol, og således presse prisen ned, kan han interessere sig for de andre købere af samme vare.

Hertil skal det føjes at det er symptomatisk, at disse fors $\varnothing \mathrm{g}$ implicerer brud på ækvivalentbyttet. Det er indlysende at profitter opnået på denne måde, intet har med produktion af merværdi at gøre. Selvom de lave priser kan indgå i en produktionspris der ligger under den gennemsnitlige, og således realisere en ekstra stor profit; men heller ikke her produceres der mere merværdi. Ekstraprofitten bliver jo netop tildelt igennem konkurrencen, ved et proportionalt fratræk i alle andres profitter $=$ afvigelse mellem værdi og pris. Den anden kilde til ekstraprofit, ikke priskartel, men produktivitetsforspring, vil vi komme ind på i slutningen af afsnittet.

Vi kan se at den kapitalistiske produktionsproces, som umiddelbar produktionsproces, i sit forhold til resten af det kapitalistiske samfund, som køber, (altså i den cirkulationsakt der indleder produktionen) er helt indenfor rammerne af simpel varecirkulation. Det er samtidig det historiske udgangspunkt for etableringen af kapitalistiske produktionsprocesser, både den oprindelige opståelse og den daglige genetablering. Denne parallelitet mellem opståelse og reproduktion er det meget vigtigt at holde fast $i$, hvis man vil gøre sig håb om at forstå, hvordan kapitalismen oprettes og reproduceres igennem subsumtion af brugsværdier.

\section{2. (V - P) Produktionsproces (V' - P')}

Vi har nu ganske kort set på den første cirkulationsakt i kapitalens kredsløb. Vi så at denne cirkulationsakt ikke havde udviklet nye bestemmelser siden pengene blev udviklet. Her ligger den afgørende diskontinuitet ikke i værdiens former, men i brugsværdisiden. Umiddelbart er det selvfølgelig arbejdskraften, der er den fundamentale diskontinuitet, men i virkeligheden kan man ikke tale om arbejdskraften uden at tale om hele den umiddelbare produktionsproces' struktur. Marx udtrykker dette ved at kalde subsumtionen formel indtil produktionens struktur direkte udtrykker merværdiproduktionen, dvs. subsumtionen er først reel med udviklingen af fabrikssystemet. Udbytningens historie op 
til da har mange eksempler på ensidige udviklinger, hvor man har lønarbejde uden fabrikker, maskiner uden lønarbejde, osv. osv. Alle disse eksempler har det til fælles, at de har et eller andet tilfældigt træk ved den reelle subsumtion, men ikke alle forholdene samtidigt og derfor ingen merværdiproduktion. Med branchens udvikling i den reelle subsumtion har den umiddelbare produktionsproces fået en teknisk struktur, der udskiller en række produktioner fra den materielle produktion. De producerer det samme, på samme måde, de udgør en produktionsgren, a branch.

Marx definerer en branche ud fra et begreb der klart er baseret på materielle forhold: den organiske sammensætning. Han bruger den organiske sammensætning til at differentiere mellem brancherne. Han differentierer, fordi han går ud fra en udviklet total konkurrence. Vi anvender den organiske sammensætning til at definere branchen, fordi vi udgår fra en situation uden kapitalistisk konkurrence.

Hvad ligger der så i den "organiske sammensætning"? I strikt forstand ligger der det, at branchens umiddelbare produktionsproces har en værdimæssig sammenhæng, der "for så vidt, den er bestemt igennem den tekniske sammensætning, og genspejler den, kan kaldes kapitalens organiske sammensætning." ${ }^{46}$ Men i virkeligheden udtrykker den organiske sammensætning et vist niveau i udviklingen af den samfundsmæssige arbejdsdeling. Den tekniske sammensætning kan først få et værdiudtryk når produktionsfaktorerne har vareform. Derfor kan man ikke opfatte landbruget i bred forstand som en branche. Først med forvandlingen af visse afgørende faktorer i produktionen, såsom arbejdskraften og tekniske forbedringer i produktionen, opstår der noget tilsvarende en branche. Men det basale forhold, at jordens pris aldrig har med dens produktion at gøre, men kun dens relative sociale placering og bonitet, gør at de branchemæssige udligninger af profitten får den modificerede form af differentialrente. Landbruget blev kommercielt, men ikke merværdiproducerende. Rederbranchen kommer til at spille en speciel rolle da den opstår i det 17. århundrede fordi dens profitudligning viser ud over den nationale basis og derfor bliver central for den merkantile politik, og dermed konsolideringen af den merkantile borgerlige stat. Omvendt bliver den statslige politik central for rederbranchens udvikling, både hvad angår dens marked og dens fixe kapital. ${ }^{47}$ Andre dele af den materielle produktion som udviklede tidlige brancher var først og fremmest klædeindustrien, bygningsindustrien, skibsbygningsindustrien, visse fødevareindustrier (især $\varnothing \mathrm{l}$ ), viser ekstraktive industrier (især kul) og endelig visse specialiserede fremstillinger som trykkerier, farvefremstilling, kanonfremstilling,

46. Karl Marx: Das Kapital III, MEW 25, s. 155.

47. Vi gennemgår rederbranchens udvikling, som en historisk eksemplificering af vores tanker om branchen, Statens Historie, del 2 s. 262-305. 
glasfremstilling osv. For alle disse områder gælder det, at de enten havde et begrænset marked, og derfor ikke lå under for det samfundsmæssige pres til at sælge varerne til deres værdi og revolutionere produktionsprocessen, eller en begrænset lønarbejdestruktur, og derfor ingen forbindelse med produktiv kapital. Her er klædeindustrien vigtigst, men hovedparten af dens lønarbejde var prækært fordi eksproprieringen af de umiddelbare producenter kun visse steder var gennemført helt frem til den frie lønarbejder. Yderligere var klædeindustriens fixe kapitals struktur meget primitiv, hvilket hindrede konkurrencebetinget $\varnothing$ gning af produktiviteten. Det var faktisk først med bomuldsindustrien i midten af det 18. århundrede at klædefremstillingen definitivt blev en branche. (Det her sagte gælder England op til 1780).

Det centrale indhold i den organiske sammensætning må derfor være $l \phi s$ rivelsen af den umiddelbare produktionsproces fra dens totale naturbundethed, og dette udtrykker sig $\mathrm{i}$, at den samfundsmæssige arbejdsdeling når et niveau, der udtrykker sig i brancher. Den samfundsmæssige arbejdsdeling er både udgangspunkt og resultat af branchens opkomst. Den samfundsmæssige arbejdsdeling er ikke et dialektisk begreb. Vi har endnu ikke bestemt branchen som en dialektisk kategori, igennem begrebet om den samfundsmæssige arbejdsdeling.

Branchens udvikling kan kun behandles konkret, som vi har gjort det med udviklingen af de nye klæder i England og med udviklingen af rederbranchen i England og Holland. ${ }^{48}$

Inden vi går videre skal vi komme med en metodisk bemærkning om opbygningen af Das Kapital. Argumentationen hele vejen igennem Kapitalen udgør en helhed, fra kapitel 4 i første bind (hvor omtalen af merværdiproduktionen starter) til kapitel $10 \mathrm{i}$ tredie bind (hvor branchen udvikles). Denne fremstilling omslutter præcis kapitalens metamorfoser fra penge til vare til produktion til flere varer og endelig merværdiens realisering i produktionsprisens oscilering omkring markedsværdien. Hele denne enorme analyse er én sløjfe der rekonstruerer én reel subsumtion. Alle de bestemmelser Marx udvikler undervejs, som ikke direkte angår den reelle subsumtion, er principielt ensidige fordi de ikke er historisk specificerede. Et eksempel er kategorien samfundsmæssigt nødvendigt arbejde der omtales i forbindelse med vareanalysen. Indenfor de tre indledningskapitler, man kunne kalde kapitlerne om pengene, kan dette begreb ikke specificeres. Det simple varebytte kender kun samfundsmæssigt arbejde og ikke samfundsmæssigt $n \phi d v e n d i g t$ arbejde - der som vi skal se, tilhører den kapitalistiske varecirkulation. I kapitel 1 specificerer Marx begrebet ud fra den vage kategori om det enkle gennemsnitsarbejde, der aldrig udvikles. Det samfundsmæssigt nødvendige arbejde bliver taget op igen, der, hvor det kan speci-

48. Se note $42,44,49$. 
ficeres, nemlig i forbindelse med markedsværdien. Her specificerer han det nu dialektisk, i forbindelse med branchen og markedsværdien.

Således må ethvert begreb der udvikles inden kapitel $10 \mathrm{i}$ tredie bind føres frem til udviklingen af kapitalismens mindste virkelighed, og specificeres derudfra. Kapitalens bestanddele, absolut og relativ merværdiproduktion, merværdirate, akkumulation, cirkuationsformer osv. er realiteter i branchen og kan specificeres der. Når Marx derfor "for tidlig" fører et begreb frem til konkurrencens "skinverden", må man ikke falde i det sorte hul det er, at lade disse ensidige demonstrationer gøre det ud for en dialektisk specifikation. Merværdiproduktionens begreber skal specificeres ud fra branchen, og de kan ikke specificeres alene, da varesamfundet ikke frembringer løsdele fra den konkret totalitet.

\section{3. (P - V, produktionsproces) V' - P'}

Lad os nu se på den anden cirkulationsakt, realiseringen af de mange umiddelbare produktionsprocessers produkter. Brancherne skal have solgt deres produkter, men med det samtidige udbud af mange varer kræves der samtidig et samfundsmæssigt behov. Vi er gået fra håndværkets bestillingsarbejde til manufakturens produktion for et massemarked. Vi er gået fra simpel varecirkulation til kapitalistisk konkurrence.

\section{Vare - Vare}

Marx skriver: "Hvad konkurrencen dernæst fuldbyrder i en enkelt branche, er dannelsen af en ens markedsværdi og markedspris af de forskellige individuelle vareværdier. Først kapitalernes konkurrence i de forskellige brancher frembringer dog produktionsprisen der egaliserer profitraten imellem de forskellige brancher. Til det sidste kræves en højere udvikling af den kapitalistiske produktionsmåde, end til den første."49 Marx opstiller nu to krav til denne branche-interne konkurrence for at markedsværdien kan tvinge markedsprisen til at svinge om den selv.

"For det første må de forskellige individuelle værdier (den individuelle umiddelbare produktionsproces' værdiprodukt) udlignes til én samfundsmæssig værdi, den ovenfor fremstillede markedsværdi, og dertil fordres en konkurrence imellem producenter af den samme slags varer, såvel som forhåndenværenden af et marked, hvorpå de sammen faldbyder deres varer. For at markedsprisen for de identiske varer, der dog er produceret under betingelser af individuel beskaffenhed, kan tilsvare markedsværdien, ikke afviger fra den, hverken igennem

49. Karl Marx: Das Kapital III, MEW 25, s. 190, se osse s. 186-7. 
forhøjelser over, eller sænkning under den, kræves, at det tryk, som de forskellige varesælgere udøver på hinanden, er stort nok til at kaste den mængde varer på markedet, som det samfundsmæssige behov kræver, dvs. den kvantitet som samfundet er i stand til at betale markedsværdien for." ${ }^{50}$

"For det andet. At varen har brugsværdi betyder kun at den tilfredsstiller et eller andet samfundsmæssigt behov. Sålænge vi kun behandlede den enkelte vare, kunne vi forudsætte, at behovet for denne bestemte vare - i dens pris var kvantummet allerede indeholdt - var for hånden, uden nærmere at gå ind på omfanget af det behov der skulle tilfredsstilles. Dette kvantum bliver dog nu et væsentligt moment, såsnart en hel branches produkt står overfor det samfundsmæssige behov. Det bliver nu nødvendigt at betragte omfanget, dvs. kvantummet af det samfundsmæssige behov." ${ }^{1}$

Det skulle være klart at der er stor forskel på de to cirkulationsakter, set fra den umiddelbare produktionsproces' synsvinkel. Disse forskelle er faktisk præcis de forskelle der udvikles med overgangen fra simpel varecirkulation til kapitalistisk varecirkulation. Denne forskel kan ikke forståes ud fra den umiddelbare produktionsproces. "Den umiddelbare produktionsproces" som formel klassifikation, er den formal abstraktion fra de utallige umiddelbare produktionsprocesser. Der eksisterer ikke en "umiddelbar produktionsproces" i almenhed, der er kun konkrete arbejdsprocesser, der ligger ved siden af hinanden. Ligeså med cirkulationsprocessen. Den er bestemt som et kontinuum af enkle subsumtioner, dvs. simpel varecirkulation. De har ikke nogen holdepunkter for en mere komplex specificering. Det kan altså kun være i en konkret umiddelbar produktionsproces og i et konkret varebytte af den kapitalistiske produktionsproces virkeligg $\varnothing \mathrm{r}$ sig. Men disse momenter modsiger alle den grundlæggende bestemmelse ved den kapitalistiske produktionsproces: at den er produktion af mere værdi i enheden af umiddelbar produktionsproces og cirkulationsproces.

I vores indledning citerede vi Marx, der hvor han indikerer, at nu springer han, hic rodus, hic salta, som han skrev da han trak arbejdskraftens værdiskabende potens ind fra højre for at specificere merværdiproduktionen. Disse små vink til læseren skal tages alvorligt. Marx gør dog ikke så meget ud af sine dialektiske overgange. Han foretager dem bare. Kun i vareanalysen er han grundig $\mathrm{i}$ sine instruktioner af læseren $\mathrm{i}$ kunsten at hoppe når man kommer til Rhodos. Dette har vi genfortalt i vores afsnit om kontinuum 1 og den feudale kongestat. I det foreliggende tilfælde skrider Marx logisk frem fra merværdien til profitraten i det første afsnit af tredie bind af Kapitalen, mens han i andet afsnit foretager springet og i tredie afsnit klarlægger konsekvenserne: profit-

50. Karl Marx, Das Kapital III, MEW 25, s. 190, vores tilføjelse.

51. Karl Marx: Das Kapital III, MEW 25, s. 194. 
ratens tendens til fald. Profitratens tendens til fald blev Marx' mest udviklede teoretiske rekonstruktion af den kapitalitiske produktionsmåde. I gangen fra afsnit 1 til afsnit 3 holder Marx sig hele tiden på værdiens side, han forfølger dens subsumtive tendens og bekymrer sig kun om de materielle-historiske forudsætninger som bifigurer. De kommer når der bliver kaldt (fordi de reelt er der hele tiden, se indledningen).

Vygodsky har i sin bog "The Story of a Great Discovery" vist, hvordan Marx i sine studier ikke kunne komme videre - virkeliggøre merværdiproduktionen, eller bringe virkeligheden på niveau med merværdien - før han udviklede sine ideer om gangen fra merværdi til profitrate (gennemsnits profitrate). Her var det afgørende gennembrud udviklingen af produktionspriserne og markedsværdien. Det synes os dog at være en mangel ved de forskellige kommentarer til Marx ${ }^{52}$ at de ikke forsøger at indtage det modsatte standpunkt, dvs. de materielle-historiske forudsætningers. Dvs. fors $\emptyset$ ge at virkeligg $\varnothing r e$, tankemæssigt rekonstruere, og opspore, subsumtionernes historiske forl øb. Alle dialektiske kategorier er historiske og kan specificeres i menneskenes verden. Marx egen analyse af lønarbejdets opkomst, i første bind af Kapitalen, viser at kategoriudviklingen må baseres historisk. Vi kan kun formode at Marx, hvis han selv havde udgivet en færdig opgave af tredie bind, ville have givet den historiske specificering af begreberne tilsvarende vægt, som i første bind. Som det er nu, bliver de materielle-historiske betingelser behandlet med venstre hånd.

Når det bliver nødvendigt at overskride den simple varecirkulations bestemmelser (hvad der viser sig ved, at argumentationen ud fra dens kategorier løber ind i selvimodsigelser) er det klart at dette må være en reflektion af, at merværdiproduktionen tilhører en højere social udvikling, end den simple varecirkulation. Her stiller vi problemet op modsat Marx, fordi det selvfølgelig ikke kræver nogen stor indsats at se at nutidens samfund er mere udviklet end den simple varecirkulation. For Marx var problemet derfor at bestemme reproduktionsmomentet, for os gælder det opståelsesmomentet - som yderligere må være reproduktionsmomentet. Pointen er at man ikke kan slutte fra reproduktionsmoment til opståelsesmoment. Vi har allerede antydet hvordan den historiske udvikling skaber brancher, men samtidig gjort det klart at brancherne defineret ud fra den samfundsmæssige arbejdsdeling (som fx. Adam Smith gjorde) ikke er en dialektisk specificering.

Marx trækker branchen ind som den materielle-historiske forudsætning for overgangen mellem værdi og profitrate. Igen ser han dog på værdisiden, og

52. Se f.ex. Vygodsky: The Story of a Great Discovery, s. 94, Rudi Schmiede: Grundproblemeder Marx'schen Akkumulations- und Krisentheorie, s. 108; Roman Rosdolsky: Zur Entstehungsgeschichte des Marxschen "Kapital", s. 440. 
koncentrerer sig om markedsværdiens rolle, mens branchernes eksistens i hans argumentation er en given historisk forudsætning. Han går ud fra konkurrencen som et umiddelbart historisk fænomen, og opdeler den i to afdelinger, dels den branche-interne, og dels den almindelige imellem brancherne. Dette er en rent analytisk opdeling, fordi der med den historiske eksistens af en samfundsmæssig gennemsnits profitrate kun er een konkurrencesfære, hvor alle varer cirkulerer mellem hinanden, hvor udligningsbevægelserne foregår på kryds og tværs imellem de enkelte kapitaler. Men i et historisk perspektiv bliver branchernes interne konkurrence tydeligt forudsætningen for den samfundsmæssige konkurrence. Så når man skal rekonstruere den historiske subsumtionsbevægelse, må man starte modsat Marx, med den kapitalistiske konkurrences fravær.

\section{Branche - Branche}

Vi vil nu, igen, forsøge os med en analogi til vareanalysen, for at fremstille subsumtionsbevægelsen ud fra et klart og enkelt grundlag. Vi er nødt til at argumentere ud fra den fiktion at der er to brancher, der står overfor hinanden, og bytter deres produkter ud mod hinanden.

Vores udgangspunkt er to kapitalistiske produktionsprocesser, beskrevet i vores lille skema, de er altså hver især enheden af umiddelbar produktionsproces og cirkulationsproces. Men de er osse hver især enheden af arbejdsproces og værdiøgningsproces. Merværdiproduktionen er samtidig kapitalitisk vareproduktionen. Som i vareanalysen står de to instanser i forhold til hinanden på en måde der logisk forudsætter en fælles kvalitet. Her er det ikke nok at sige at det er det abstrakte samfundsmæssige arbejde. Denne bestemmelse er for lille til at udtrykke den aktuelle fælleskvalitet. Der hvor de står i forhold til hinanden er de varer, og ikke kun varer,- men kapitalistiske varer. Deres fælles kvalitet er deres kapitalitiske vareproduktion, hvor hver eneste vare indeholder værdi og brugsværdi, men ikke kun det, osse merværdi og branche-specifik brugsværdi.

Den enkelte kapitalistiske produktionsproces' indre modsætning mellem arbejdsproces og værdiøgningsproces er direkte reproduceret i den kapitalistiske vares indre modsætning, af henholdsvis arbejdsprocessens produkt: den branche-specifikke brugsværdi, og værdiøgningsprocessens produkt: værdi + merværdi. Vi skal her bemærke at gangen fra produktionsproces til vare, ikke er nogen "cirkulation" eller lignende, men den simple genstandsgørelse af produktionsprocessen, hvor dens forskellige elementer er reproduceret, eller har genstandsgjort sig. Med gangen fra produktionsproces til vare er der sket en fysisk forandring som danner forudsætningen, ikke indholdet i cirkulationsakten $\mathrm{V}^{\prime}$ - P'. 
Hvis vi nu kalder branche A for rugbrødsbagerbranchen, og branche B for guldminebranchen, så vil vare $\mathrm{A} \mathrm{i}$ bytteforholdet med vare $\mathrm{B}$ udtrykke sin værdi i vare B's brugsværdi. Dvs. at rugbrødsmassen udtrykker sit indhold af samfundsmæssigt abstrakt arbejde i guldmassens direkte brugsværdi. Men der udtrykkes jo mere: rugbrødsmassens indhold af abstrakt samfundsmæssigt arbejde er en reproduktion af produktionsprocessen, altså kan vi genfinde produktionsprocessens værdikategorier, hvor den vigtige er forholdet mellem den reproducerede værdi og den tilsatte værdi: merværdiraten. Merværdiproduktionen udtrykker sig i guldmassens brugsværdi. Men denne brugsværdi udtrykker mere: det er en specifik brugsværdi, en brugsværdi af et specifikt omfang. Guldmassen udtrykker derfor ikke kun det samfundsmæssigt abstrakte arbejde men netop det samfundsmæssigt $n \phi d v e n d i g e$ arbejde.

Guldmassens specifikke omfang er guldminernes samlede produktion, i vores fiktive kapitalisme. Guldminernes kapitalistiske vareproduktion udtrykkes relativt af så og så meget rugbrødsmasse, dvs. bageriernes kapitalistiske vareproduktion. I vores fiktive kapitalisme forudsættes det selvfølgelig at bagerierne har brug for guld-massen, at den har brugsværdi for dem. Og yderligere at disse behov præcis har det omfang som den modsatte branches produktmasse.

Bageriernes forbrug af samfundsmæssig arbejdstid udtrykkes i guldminernes konkrete forbrug af arbejde. Vi kan osse sige at bageriernes forbrug af arbejde bliver målt som forbrug af samfundsmæssig arbejdstid når rugbrødsmassen bliver byttet med guldmassen, når rugbrødsarbejdets samfundsmæssige bestemmelse bliver målt i guldminearbejdets konkrete resultat, guldmassen.

Vi når frem til at bageriernes modsætningsfulde enhed af arbejdsproces og værdiøgningsproces, hhv. rugbrødsmassens modsætningsfulde enhed af værdi + merværdi og brugsværdi, kun kan udtrykkes, have social realitet, når den kapitalistiske produktionsproces står i et bytteforhold til en anden kapitalistisk produktionsproces. Rugbrødsmassen byttes mod guldmassen: rugbrødsmassen udtrykker sit forhold af værdi + merværdi i guldmassens brugsværdi $o g$ dens specifikke omfang. Guldmassen bliver det umiddelbare udtryk for bageriernes værdiøgningsproces, dens ækvivalent. Men denne ækvivalent er osse resultat af en kapitalistisk produktionsproces, ækvivalenten er derfor guldminernes arbejdsproces,- som den genstandgør sig i guldmassen. Og således udtrykker guldmassens konkrete omfang rugbrødsmassens specifikke indhold af samfundsmæssigt nødvendigt arbejde.

\section{Profitrate - Profitrate}

Vi skal nu ophæve vores fiktion, at de to brancher har behov og produktion der muliggør et lige bytte. Det er nemlig en fiktion, at den kapitalistiske varepro- 
duktion uden videre kan regne med en produktion der fuldstændig svarer til et betalingsdygtigt samfundsmæssigt behov. Imellem alle brancherne står konkurrencen som formidling, hvor det der direkte står overfor den enkelte branche er det samfundsmæssige behov for branchens produktmasse, i form af et betalingsdygtigt behov. Det er altså en vis sum penge, bestemt kvantitativt af et samfundsmæssigt behov, der står overfor branchen. ${ }^{53}$

Men da det centrale for den kapitalistiske produktionsproces er produktionen af mere værdi, så følger heraf at branchen vil forsøge at drive plusmageriet ud over alle grænser. Hvilke grænser er der? For den enkelte lille bojar kapitalist, er afhændelsen, salget af produkterne, grænsen. Den eksisterer for ham som en maximal pris. Men prisen er kun det forvandlede udtryk for varens værdi, dens indhold af samfundsmæssig nødvendig arbejde. Prisen er den dom der fældes over branchens brug af samfundsmæssig arbejdstid. For branchen falder værdien og prisen i dens givne produktmasse kun sammen, når den lige har ramt det samfundsmæssige behov i øjet. Således forvandles merværdiraten til profitrate i produktionsprisen (markedsproduktionsprisen), hvor profitraten giver mulighed for afvigelsen mellem værdien og prisen. Således bliver kapitalen virkeliggjort som en relation til sig selv, som en rate.

Herfra går kursen videre til krisebegrebet og profitratens tendens til fald. Vi skal ikke tage dette op her, men vil vende tilbage til det i forbindelse med vores almindelige arbejde med kapitalismens historiske udvikling. Paul Mattick skriver: "Det er sandt, at værdiloven... ikke er et iagttageligt fænomen, men tager form af priser og kun gør sig gældende i den kapitalistiske krise. Men fordi den gør således, er det klart, at værdi kun er det feticherede, borgerlige udtryk for reelle samfundsmæssige produktionsrelationer og tidselementet, som determinerer værdirelationer." 54

Som udgangspunkt havde vi den enkelte kapitalistiske produktionsproces, der sælger sine varer for et socialt behovs penge. Dette er stadig et værdiudtryk mellem to varer, en enkel subsumtion. Dernæst viste vi hvordan dette værdiudtryk er for lille til at give udtryk for den specifikke modsætning i den kapitalistiske vare. Denne vare er reproduktionen af den kapitalistiske

53. "Det skal her bemærkes, i forbifarten, at det "samfundsmæssige behov", dvs. det der i princippet regulerer efterspørgslen, i det væsentlige er bestemt gennem de forskellige klassers forhold til hinanden og gennem deres respektive $\varnothing$ konomiske position, dvs. for det første gennem totalmerværdiens forhold til arbejdslønnen og for det andet de forskellige deles forhold, hvori merværdien spalter sig (profit, rente, grundrente, skatter osv.) og således viser det sig atter, hvorledes absolut intet kan forklares ud fra efterspørgsel og udbud, før man har udviklet den basis, hvorpå disse forhold udspilles." Karl Marx, Das Kapital III, MEW 25, s. 191.

54. Paul Mattick i et svar på Statens Historie, del 2, sidste afsnit. 
produktionsproces' modsætning mellem arbejdsproces og værdiøgningsproces - merværdiproduktion. Grunden til at det ikke er den enkelte kapitalistiske produktionsproces, men branchen, der er kapitalismens mindste virkelighed, er derfor, at mervardien ikke kan komme til sig selv i den enkle subsumtion (varebyttet), men nødvendigg ør en samfundsmæssig artikulation, der både revolutionerer produktionsprocessen og cirkulationsprocessen. Merværdiproduktionen må artikuleres umiddelbart. Det mindste moment dette kan ske i er branchen, fordi det er det mindste værdiforhold mellem kapitalistiske produktionsprocesser. Her omvæltes et afsnit af den materielle produktion igennem tvangen til at overholde den gennemsnitlige profitrate. De mange ens produktionsprocesser bliver først til en distinkt branche når denne helhed har manifesteret sig om forudsætningen for udviklgngen af branchens distinktioner. Det afgørende punkt i de mange ens umiddelbare produktionsprocessers voksen sammen til en branche, bliver deres mulighed for at konkurrere med hinanden på basis af produktiviteten realiseret som deres individuelle kapitalproduktivitet (af kapitalisten opfattet $\mathrm{i}$ priser).

Vi viste dernæst hvordan værdiudtrykket forvandledes fra at statisk kvalitativt, i den enkle subsumtion - hvor kun værdiens substans, det samfundsmæssige abstrakte arbejde - blev virkeliggjort; til et dynamiskkvantitativt i den reelle subsumtion. Nu udtrykkes ikke bare værdiens substans, men osse dens størrelse (tilvækst) - det samfundsmæssigt $n \phi d v e n d i g e$ arbejde - ved et analogt værdiudtryk mellem to konkrete instanser, to brancher (hvor varerne nu er reduceret til "elementarform"). Denne subsumtionsbevægelse, der opretter en bevægelsesform for den kapitalistiske produktions indre modsigelse, er altså sammenknytningen af en række ens umiddelbare produktionsprocesser og cirkulationsprocessen. Herved kan mervardiproduktionen virkeliggøre sig som en branches gennemsnitsprofitrate. Det er kapitalismens mindste virkelighed.

Vi mener selv at denne bestemmelse af kapitalismens mindste virkelighed har enorme konsekvenser for analysen af kapitalismen. Det er et postulat indtil videre fordi vi først når dette offentliggøres, er igang med analysen af kontinuum 2's udvikling i den industrielle revolution, og dette kontinuums komplexe subsumtion af den merkantile borgerlige stat. Dvs. at vi indtil nu, kun har unders $\varnothing$ gt pengenes statsformer: den feudale kongestat, den absolutistiske kongestat og overgangsformen den merkantilistiske borgerlige stat. Kapitalens statsformer er endnu kun hypoteser og ligeledes kapitalens produktionsmåde og verdensmarked. Forhåbentlig vil vi være i stand til at offentliggøre vores resultater herom på et senere tidspunkt. 


\section{B. Guld og penge}

Den følgende bemærkning om penge og guldstandarden, er et resultat af en tilfældig udviklingslinie frem i tiden, fra perioden før kapitalismen. Vi har medtaget den netop som et eksempel på et perspektiv der ligger i en historisk specificering af begreberne, selvom vi ikke når til en gennemargumenteret konklusion vedrørende penge - verdenspenge - guldstandard.

Derimod forsøger vi at sandsynliggøre at kapitalismens udfoldelse er en fremadskridende proces, der f.eks. forandrer pengene, så de først nu når en form der svarer til kapitalismen selv, i modsætning til guldet der hører en førkapitalistisk epoke til.

Vi skal her undersøge guldet, dvs. monetært metals betydning for den historiske udvikling af pengevaren. Vi skal forsøge en kort rekonstruktion af guldets funktion som almen ækvivalent, og vise hvordan pengene stadig reproduceres i nye modificerede former, fordi modsætningen mellem værdi og brugsværdi, mellem privat og samfundsmæssigt arbejde parallelt udvikler sig. ${ }^{55}$

\section{Rene guldpenge}

I denne sammenhæng er der tale om perioden fra middelalderen op til de borgerlige revolutioner i Europa og USA, dvs. op til 16 og 1700-tallet.

Guldpengene var nedarvet fra antikken og forsvandt aldrig helt, selvom pengecirkulationen i den tidlige middelalder har været meget begrænset. Der hvor vi her tager tråden op, er det tidspunkt hvor den feudale kongestat overtager møntudstedelsen som et statsligt anliggende, i kamp mod store herremænd og klostre der tidligere gjorde sig på dette område. I England kan dette, relativt tidligt i forhold til resten af Europa, dateres til 1100-tallet.

Existensbetingelserne for de historiske penge fremstiller vi her kun rent skematisk, uden at nævne de nærmere praktiske omstændigheder. De historiske penge er den umiddelbare virkelige manifestation af den almene ækvivalent. Ækvivalentformen er resultatet af ethvert varebytte, enhver enkel subsumtion. Den almene ækvivalent er resultat af den enkle subsumtioners gentagelse, af markedets udvikling. Det fører videre til Kontinuummet af enkle subsumtioner, eller Kontinuum I.

Manifestationen af Kontinuum I udtrykker en stærk social forandring i denne periode: en bestemt vare taber sin bytteværdi og bliver til ren brugsværdi og er som sådan inkarnationen af alle andre varers bytteværdi; guld bliver til penge. Da "abstraktionen" fra pengevarens bytteværdi er rent samfundsmæssig, forud-

55. Se hertil Statens Historie II s. 1-13 og 230-261. 
sætter den samtidig en social struktur der kan opretholde denne "abstraktion". Denne struktur er kongemagten der i sin funktion som pengenes opretholder bliver til stat, kongestaten, igennem kontinuummets komplexe subsumtion af den givne feudale kongemagt. De historiske penges existensbetingelser er derfor i dette tilfælde den givne historiske mulighed for kongemagtens komplexe subsumtion: Er markedet stærkt udviklet, er det domineret af udenlandske købmænd, er bønderne aktive på markedet, er kongeslægten stærk, er der en arving, er der ædelmetaller i riget osv.

Det er først og fremmest mønter, der fungerer som penge i praksis. Dette er ganske vist modificeret på forskellig måde. Dels af forsøg med papirpenge og dels af forskellige overførselsanvisninger. Papirpenge experimenterne varede sjældent ret længe, mens anvisningerne fungerede udmærket op gennem middelalderen, men udelukkende på grundlag af den almindelige guldcirkulation.

Det afgørende historiske moment, der ligger bag ved pengenes og statens udvikling i denne periode, er overgangen til pengerente i det feudale landbrug, en kommutering der satte ind allerede i 1100-tallet. Heri ligger en samfundsmæssiggørelse af selve merproduktet, idet bonden nu må sælge en del af sine produkter på markedet for at betale herremanden med penge. Den altovervejende del af produktionen konsumeres direkte af de umiddelbare producenter, selvom der generelt for hele perioden sker en stadig udvidelse af markedet udover hvad der er nødvendigt for realiseringen af renten.

Pengeformen manifesterer sig som guldmønter, dvs. genstandsgjort menneskeligt arbejde i konkret materiel form, fordi bytteværdien ikke kan antage nogen form på dette tidspunkt. Det skyldes at bytteværdiens oprindelse i produktionen, dvs. det gennemsnitligt nødvendige menneskelige arbejde, kun har ringe mulighed for at "slå igennem". Det er der to årsager til. 1) Den overvejende del af produktionen, i det feudale landbrug, var ekstremt følsomt for tilfældige udsving $\mathrm{i}$ arbejdets produktivitet, først og fremmest p.gr.a. naturens luner. 2) Ikke-ækvivalentbyttet var reglen snarere end undtagelsen, specielt indenfor fjernhandelen, og i det hele taget den del af handelen der domineredes af handelskapitalen. Handelskapitalen var på den ene side beskyttet af den feudale stat, gennem politiske monopolordninger, samtidig med at den som kapitalform overhovedet hviler på ikke-ækvivalentbyttet.

Ikke-ækvivalentbyttets dominans udgør en stadig trussel mod pengeformen, når denne opfattes som det umiddelbare udtryk for bytteværdien. Denne trussel afværges med guldpenge fordi de, netop som varer blandt andre varer, kan opretholde bytteværdiens manifestation i pengene, ved selv at være genstandsgjort menneskeligt arbejde. Endvidere er guldet stort set produceret udenfor den feudale produktionssfære, ligesom dets pris ikke kan fastsættes arbitrært af staten og handelskapitalen, dels fordi dette ville undergrave selve pengeformen, 
i modsætning vil statens egne interesser og dels fordi guldet som "internationalt" betalingsmiddel ikke kunne prisansættes afgørende forskelligt mellem de forskellige lande eller riger.

Sammenfattende kan vi sige, at pengeformen i denne periode bliver den feudale stats anliggende, og at pengeformen under den feudale stat var begrænset til guldpenge.

Den nærmere sammenhæng mellem staten og pengene under feudalismen, og handelskapitalen og ikke-ækvivalentbyttet, kan man læse om i vores to rapporter. ${ }^{56}$

\section{Papirpenge med guldindløselighed}

Denne periode starter groft sagt med de borgerlige revolutioner, og dermed med store afvigelser fra land til land; men den slutter til gengæld næsten samtidig i alle lande, nemlig med guldstandardens afskaffelse i 1930'erne. Guldstandarden gik i opløsning under I verdenskrig, men blev genoptaget i 20'erne. I forbindelse med 30'ernes krise brød den endeligt sammen.

Med guldstandarden trækker guldet ind i bankenes boxe, mens guldindløselige papirpenge cirkulerer som national valuta. Guldet fortsætter som internationalt betalingsmiddel. Fordelen er at guldbeholdningen kan være langt mindre end pengesedlernes pålydende. Guldet hører op med at fungere som betalingsmiddel, men bevares som regnepenge og værdimål.

At systemet ikke er helt så enkelt i praksis skal vi her lade bankmændende og pantefogederne om. Vi skal koncentrere os om hvilke historiske faktorer, der er grundlaget for at papirpenge kunne komme for at blive, og dermed etablere en pengeform, der var et mere dækkende udtryk for pengenes begreb. Pengenes begreb udtrykker den konkrete ligesætning af menneskeligt arbejde der hele tiden foregår i de mange oprettelser af vareformer som cirkulationen indebærer. I denne forstand er papirpengene i bedre overensstemmelse med den sociale relation de udtrykker, nemlig bytteværdien. Guldet lider jo af den egenskab at være vare blandt andre varer, mens papiret blot er et symbol på den konkrete lighedsætning der er forudsætningen for byttet.

De engelske guldindløselige papirpenge indføres for alvor med Bank of Englands oprettelse i 1694. Bank of Englands noter holder sig næsten uden afbrydelse op til vore dage, med visse korte afbræk. Det er derimod karakteristisk at Laws storstillede fors $\varnothing \mathrm{g}$ på at indføre papirpenge i Frankrig i 1719-20 går fuldstændig i vasken og udelukker denne mulighed for Frankrings vedkommende helt op til revolutionen i 1789. Den store financielle krise i Vesteuropa

56. Ibid. 
i 1720 berører også England, men her kommer man hurtigt på fode igen, med den borgerlige merkantile stat og produktionens befrielse for de feudale restriktioner i baghånden. ${ }^{57}$

Som følge af de borgerlige revolutioner hæves de feudale restriktioner af produktionen både i landbruget og for anden vareproduktion. Den feudale stats greb om produktion og cirkulation opløses og det nationale marked kan arkikulere sig frit. Selve produktionsprocessen ændres til at begynde med kun langsomt, men forandringen accelererer betydeligt i forbindelse med de første brancher. Det gælder ikke mindst for det engelske tilfælde, mens de senere borgerlige revolutioner fører til en hurtigere udvikling af produktionen, bl.a. p.gr.a. presset på verdensmarkedet fra England, som det første kapitalistiske land.

Med de forskellige branchers dannelse under disse nye markedsforhold og den borgerlige merkantile stat, vokser selve kapitalismen op, også først i England, men derefter i Nordamerika og hele Vesteuropa. Guldindløselige papirpenge vinder overalt frem og anderkendes af alle, også marxister, som den eneste praktisk anvendelige måde at ordne det borgerlige samfunds pengesystem på. ${ }^{58}$

Men i forbindelse med mellemkrigstidens financielle vanskeligheder og den borgerlige industrielle stats voksende financieringsbehov, bryder guldstandarden sammen og erstattes af rene symbolpenge. Dette betragter vi som en følge af kapitalismens konsolidering eller fulde gennemslag på nationalt plan, hvilket vi skal komme nærmere ind på i diskussionen af den tredie periode.

\section{Rene symbolpenge}

I løbet af 1936 var guldindløseligheden for alle nationale valutaer ophævet, med den vigtige modifikation at \$ stadig var indløselig for ikke-amerikanske \$ besiddere. Det var altså udelukkende $\$$ som verdenspenge der opretholdt indløseligheden, og ikke \$ som national penge i USA. USA'ske borgere blev ganske enkelt forbudt at eje guld som andet end tænder og pynt.

Men hvad var der sket, hvordan kunne guldet undværes og hvorfor valgte man at undvære det?

Som en slags indledning til spørgsmålet kan vi referere til Palyi: The Twilight of Gold, der repræsenterer det udprægede "gammel liberalistiske" synspunkt. Han mener ikke at det i det hele taget var nødvendigt at gå bort

57. Se Statens Historie II s. 197-228.

58. Melchior Palyi: The Twilight of Gold 1914-1936, Chicago 1972, s. 341. 
fra guldet, men at det skete som følge af" ...tilfældige ulykker og menneskelig svaghed". ${ }^{59}$ Hans hovedanke mod guldets afskaffelse, er at den betød en overvældende styrkelse af staten, til skade for "manden på gaden". Styrkelsen består i at staten nu får mulighed for inflationær deficit financiering, således at borgerne mister kontrol med staten. At manden på gaden i guldets tid skulle have haft magt over staten med truslen om veksling af sedler til guld, er nok en tvivlsom affære, men der er ingen tvivl om at statens financieringsgrundlag blev betydeligt udvidet med afskaffelsen af guldets tvang. Den inflationære pengeudstedelse kan betragtes som en ny form for beskatning, idet inflationen rammer enhver med fast pengeindkomst. Skal man således forstå den umiddelbare årsag til guldets endelige detronisering som almen ækvivalent, er det '30ernes krise og den nye deficit financiering man skal koncentrere sig om. Dermed har man dog ikke forklaret hvordan denne mulighed var opstået.

Vi mener at muligheden foreligger med en vis udvikling af den kapitalistiske produktion. Den første forudsætning er at der udvikles en gennemsnitlig profitrate mellem flere nationale brancher. Dette sker relativ tidligt i England, mellem 1780 og 1830, hvorefter frihandelen slår igennem og fagforeninger gøres lovlige i løbet af 1830erne og 40erne.

Eet særligt punkt vil vi tage ud, af speciel betydning for guldindløselighedens afskaffelse under kapitalismen, og det er arbejdskraftens udvikling til at blive varen arbejdskraft. Ovenfor har vi præciseret, hvordan lønarbejdet skal opfattes til forskel for "arbejde for løn" under feudalismen og i overgangsperioden. Vi mener ikke, at arbejdskraften umiddelbart bliver til en vare historisk set, med etableringen af kapitalistiske produktionsprocesser. For at denne kategori skal danne nogen mening må man kræve at varen arbejdskraft er "produceret" indenfor det kapitalistiske system, der gør arbejdskraften til vare. Selve den kapitalistiske produktion i fabrikshallerne må have lejlighed til at gøre arbejdskraftens reproduktion til sin sag, først ved at trække arbejderne ind i fabrikken og derefter gøre dem til forbrugere af industrivarer, med et reproduktionsniveau der står i forhold til den produktivitet som selve fabrikssystemet indvarsler. Dette indebærer samtidig at arbejderklassens organisering i fagbevægelsen integreres i den borgerlige offentlighed; i første omgang ved at fagforeningerne og arbejderpartierne legaliseres og dernæst at deres krav bringes på linie med den borgerlige økonomis afgørelse af, om kravene er i overensstemmelse med akkumulationstvangens påbud.

59. Vi er ikke istand til på nuværende tidspunkt at angive nærmere, hvornår vi mener varen arbejdskraft realiseres historisk. Vi arbejder selv videre med problemet og håber at andre vil gøre det samme. Det er klart at dette problem vil tage sig forskelligt ud i forskellige lande. I Nordeuropa vil socialdemokratiets udvikling være betydningsfuldt, mens dette f.ex. ikke er tilfældet i Sydeuropa og USA ect. 
De første brancher der opstår, kan trække på en arbejdskraft der er "produceret" af en anden produktionsmåde. Arbejderen er vant til kontraktlige forhold på et personligt niveau mellem ham og arbejdskøberen. Ofte har han før haft mulighed for, og været nødt til, at dyrke lidt jord ved siden af. Kampen for dagen og vejen kunne ikke blive kollektiv p.gr.a. smådriften og opsplitningen af arbejdskraften.

Med industrialiseringens hastige fremmarch dannedes en arbejderklasse af folk der kun i deres elendighed var tvunget til at tage arbejdet under umenneskelige betingelser og til en løn der ikke kunne reproducere arbejderklassen som sådan. Forsvarsløs af mangel på erfaring med og mulighed for kollektive kampmidler, blev arbejderklassen udsat for noget der kunne ligne kapitalisternes fors $\emptyset \mathrm{g}$ på een gang for alle at presse alt merarbejde ud af underklassen. Med børnearbejde og 16 timers arbejdsdag, var kapitalen ved at slå sit eget grundlag ihjel. Samtidig var udbytningsraten høj og flot, mens merværdien kun kunne realiseres ved at en del af produktionen blev afsat på verdensmarkedet.

Produktivitetsstigningen kom til bl.a. at udtrykke sig i en langt større varemasse, hvor hver vare indeholdt mindre arbejde. Det revolutionerede arbejderklassens materielle grundlag og integrerede den i det borgerlige samfund. På denne måde blev arbejderklassens reproduktion bestemt af kapitalismen selv, man kan nu tale om at arbejdskraftens pris svinger omkring dens værdi. Varen arbejdskraft kan siges at være kommet til sig selv som historisk faktum.

Dateringen af denne historiske proces er temmelig uensartet, men følger andre træk ved kapitalismen i at være tidligst i England, og accelerere i andre lande efterhånden som kapitalismen breder sig i Vesteuropa og USA.

Siden pengene er det konkrete udtryk for bytteværdien og dermed også det umiddelbare udtryk for værdiens substans, det gennemsnitlige samfundsmæssige menneskelige arbejde, må vi antage at pengenes praktiske form som rene symbolske penge, først er muliggjort under kapitalismen med varen arbejdskrafts egentlige realisering. Først med denne realisering er den reelle subsumtionen nået i bund og har skabt en konkret historisk bærer af værdiens kilde, på linie med værdiens første historiske form, nemlig bytteværdien i varebyttet.

Når marxistiske skribenter i 1920erne fastholdt guldstandarden som en nødvendighed under kapitalismen, var det formodentlig en følge af, at de betragtede den daværende kai italisme som den højst muligt udviklede kapitalisme, og dermed gik ind på de umiddelbare administrative vanskeligheder afskaffelsen indebar, i stedet for at gøre sig klart hvilke muligheder der lå i en yderligere kvalitativ udvikling af kapitalismen.

Det samme gør sig tilsyneladende gældende når folk som Altvater og Neusüss fortsat insisterer på guldets nødvendighed som verdenspenge, på trods af at gul- 
dets praktiske betydning for verdens valutasystem nu er forsvindende. Ganske vist ligger visse lande, inklusive USA, stadig inde med valutareserver i form af guld, men dette berører i realiteten ikke længere pengeformen som sådan.

\section{Exit guld}

Efter guldet i praksis er afskaffet og de nye valutaaftaler forpligter deltagerlandede til ikke at lade deres valutaer følge guldet, bliver det vores opgave at forklare hvad der betinger dette. Vi kan imidlertid ikke entydigt vise at guldstandarten virkelig også er afskaffet for evigt, fordi vores angivelser af årsagen til guldets afskaffelse indtil nu kun er hypotetiske.

Den umiddelbare årsag til at guldet afskaffes netop nu, dvs. i 1973, er naturligvis USAs relative svækkelse i forhold til de andre store kapitalistiske lande. Valget stod mellem at forhøje den gamle officielle guldpris på $35 \$$ til det mere realistiske $100 \$$ som var gældende i handel og vandel, eller at gå helt bort fra guldet. Det var selvfølgelig praktiske overvejelser, der gjorde, at man valgte det sidste. Det er ikke ud fra disse overvejelser vi kan finde frem til den udvikling af kapitalismen som verdenssystem, der kan begrunde at guldet kan forlades.

Mens vi mener, at betingelsen for de enkelte nationale valutaers uafhængighed af guldet var realiseringen af varen arbejdskraft og dens reproduktion indenfor de nationale kapitalismer, mener vi, at dette først kan slå igennem på verdensmarkedet ved en svækkelse af handelskapitalen, henholdsvis styrkelse af den produktive kapital på verdensmarkedet.

Handelskapitalens dominans på de nationale markeder i de kapitalistiske lande blev tilendebragt med den produktive kapitals fremtrængen i 1800- og begyndelsen af 1900tallet. Men dette slog ikke igennem på verdensmarkedet p.gr.a. kapitalismernes relative isolation indenfor nationerne. Handelskapitalen havde gode muligheder for at berige sig på grundlag af de forskellige gennemsnitlige nationale produktivitetsniveauer, som skitseret nedenfor.

Handelskapitalens profitform afhænger af brud på ækvivalentbyttet, i modsætning til den produktive kapital. At købe billigt og sælge dyrt, det er princippet for handelskapitalen, der ikke kontrollerer produktionsprocessen. Vores hypotese er nu at handelskapitalen, eller ikke-ækvivalentbyttet er dominerende på verdensmarkedet op til efter II verdenskrig. Denne dominans kan først brydes af egentlige internationale eller overnationale brancher, gennem hvilke den gennemsnitlige profitrate kan virkeliggøres på tværs af landegrænserne, men $p r$. branche. Vi må understrege at denne udvikling foregår branche for branche og ikke nation for nation. Den produktive kapitals dominans på verdensmarkedet, er forudsætningen for guldstandardens afskaffelse. Først 
når ikke-ækvivalentbyttet fortrænges kan pengeformen fungere uden guldet. Dette kan vi indtil nu kun fremlægge som en hypotese. Vi har ikke formået at sammenknytte pengeformen som den praktisk fungerer i statsligt regi, med den kapitalistiske vareproduktions udviklingsgrad. Dog må vi fastholde at selve pengeformen kun danner mening i vareanalysen, under forudsætning af ækvivalentbyttet. Derfor finder vi det nærliggende at antage at den tvang, der ligger i guldpengenes specielle karakter, må betragtes som nødvendig for og et udslag af at vareudvekslingen domineres af ikke-ækvivalentbyttet. Vi mener, at løsningen skal søges i reduktionen af det konkrete arbejde til abstrakt forskelsløst arbejde. Vi formoder, at problemet vedrørende penge uden guld, kan løses gennem en opklaring af dette dunkle punkt i marxismen.

Uanset om læseren er uenig med os om, hvordan guldet nu også er effektivt afskaffet på verdensmarkedet, vil vel ingen hævde at guldet kun midlertid er afskaffet indenfor de nationale kapitalismer.

Vi vil nu stille spørgsmålet, hvad er verdenspenge? idet vi på forhånd må sige at vi kun når frem til at sige hvad det ikke er.

\section{Hvad er verdenspenge}

Ovenfor har vi argumenteret for at guldpenge må betragtes som et primitivt udtryk for penge. Den reelle subsumtions stadig mere omfattende reproduktion er grundlaget for at de historiske penge gradvist mere rent udtrykker pengenes begreb. Dvs. at "værdiens substans" det "abstrakte menneskelige arbejde", får en stadig mere konkret og sammenhængende historisk eksistens. Når vi nu skal se på problemet verdenspenge i denne forbindelse, må vi gøre klart hvordan selve verdensmarkedet skal opfattes i forhold til den materielle produktion, for derigennem at forstå det materielle grundlag for verdenspengene.

Verdensmarkedet er umiddelbart blot den internationale cirkulationssfære for varer af enhver art, uanset om de er produkter af kapital eller ej. Siden verdensmarkedet er enbart domineret af de kapitalistiske nationer, bliver verdensmarkedet ofte kaldt kapitalistisk. Det mener vi ikke man umiddelbart kan gøre.

Set fra de kapitalistiske nationers synspunkt er der hovedsagelig to instanser der står overfor hinanden på verdensmarkedet. Dels de enkelte brancher der udgør kapitalistisk producerende enheder, og dels staterne i de enkelte nationer. Kun gennem staten står "de nationale totalkapitaler" overfor hinanden på verdensmarkedet. Heri ligger en modsætning der gør det vanskeligt at tale om et egentligt kapitalistisk verdensmarked. På den ene side står brancherne i de enkelte lande overfor hinanden, (eller der dannes internationale brancher, der må betragtes som udfoldelsen af et egentligt kapitalistisk verdensmarked), på 
den anden side fortsætter nationalstaterne som feudale rester der hindrer kapitalens "overnationalisering" og beskytter nationale kapitalafsnit, brancher eller enkelte fabrikker, mod den store verdens anslag. Det er på denne baggrund handelskapitalen har kunnet fortsætte sin domimans på verdensmarkedet langt efter industrikapitalens sejr indenfor de kapitalistiske nationer. Kun gennem branchen kan den gennemsnitlige profitrate realiseres og kun gennem internationale brancher kan et kapitalistisk verdensmarked udvikle sig.

De forskellige nationers valutaer og deres udveksling er en af betingelserne for at de forskelligt udviklede nationale enheder kan sameksistere og at der gradvist kan dannes internationale brancher.

Samtidig er valutaudvekslingssystemet en af årsagerne til at der ikke dannes egentlige verdensmarkedspriser, hvor prisen svinger omkring værdien; der opstår ingen bevægelsesform for "universelt arbejde", fordi valutaudvekslingerne beskytter den fortsatte eksistens af adskilte kapitalistiske virkeligheder. Mens de ikke-kapitalistiske lande, u-lande s.k., ikke er beskyttet mod verdensmarkedet tilstrækkeligt herigennem; men holdes tilbage i national ikke-kapitalisme.

Den enkelte "kapitalismes" penge er udtryk for arbejdets gennemsnitlige produktivitet indenfor denne "kapitalisme", på tværs af de enkelte branchers forskellige produktivitet. Dette nationale pengeudtryk opstår på betingelse af dannelsen af en gennemsnitlig profitrate i brancherne og mellem brancherne. På verdensmarkedet kan den gennemsnitlige produktivitet ikke slå igennem, fordi "kapitalismerne" er beskyttet af staten indenfor deres nationale begrænsninger, netop igennem de nationale valutaer.

De enkelte DM, Kroner eller \$ udtrykker således forskellige kapitalistiske gennemsnitsbetingelser som nationale valutaer, mens det der udveksles er varer produceret i enkelte landes brancher, der ikke som brancher betragtet behøver at være udtryk for hele nationers gennemsnitlige produktivitet. Der hvor de internationale brancher slår igennem, dvs. brancher i hvilke der opstår en gennemsnitlig produktivitet på tværs af landegrænserne, dannes der tendentielt en kapitalistisk virkelighed på selve verdensmarkedet, udenom staten, valutaen og nationen. Her skabes for første gang muligheden for egentlige verdenspenge og verdensmarkedspriser. Tilsvarende indenfor de multinationale selskaber, der overfører varer og værdier fra land til land, uden nogen form for penge, men kun som bevægelser i deres regnskaber.

Men hvad er situationen før de internationale brancher dominerer verdensmarkedet, dvs. nu?

Her udveksles varer der er produceret af en national branche, hvis pris udtrykkes og må erlægges i national valuta. Her må den enkelte branche konkurrere med andre nationers brancher på prisen, men prisen formidlet 
gennem nationens gennemsnitlige produktivitet udtrykt $i$ nationens valuta. Den højproduktive branche har en fordel i sin høje produktivitet, men denne fordel modificeres på verdensmarkedet af resten af nationens gennemsnitlige produktivitet.

Mens én nations valuta udtrykker denne nations gennemsnitlige produktivitet, findes der ingen verdenspenge der kan udtrykke en gennemsnitlig verdensproduktivitet, fordi en udligning af profitrate og produktionsbetingelser i det hele taget kun slår igennem langsomt mellem nationerne. Mao: verdensmarkedet er endnu ikke kapitalistisk.

Spørgsmålet er nu hvad der kommer til udtryk i vekselkurserne. Her må vi gå ud fra at vekselkurserne tenderer mod en udligning af de mange valutaers købekraft i forhold til hinanden. Dvs. at den gennemsnitlige produktivitet i det ene land sættes lig den gennemsnitlige produktivitet i det andet gennem valuta udvekslingen. "Gennemsnitsvaren" fra det ene land koster gennem valutaveksling det samme som "gennemsnitsvaren" fra det andet.

Men hele humlen er at der ikke findes anden "gennemsnitsvare" end netop pengene selv, mens de mange forskellige varer er produceret med højst forskellig produktivitet i forhold til den gennemsnitlige indenfor samme land. Hovedårsagen til afvigelser i valutakurser fra en lighedssætning gennem valutaveksling af gennemsnitlig købekraft, er at brancher i et land hvis produktivitet er højere end landsgennemsnittet, kan være af større eller mindre betydning for udenrigshandelen. Tilsvarende er hovedårsagen til ændringer i valutakurserne den forskudte udvikling af landenes eksportbrancher.

Her må vi tilføje endnu en faktor, der forhindrer verdensmarkedet $i$ at blive kapitalistisk, og det er, at arbejdskraftens værdi (her lig pris) er forskellig fra land til land af ikke-kapitalistiske historiske årsager. Den vigtigste er at arbejdskraftens mobilitet er så ringe i forhold til kapitalens. Dette forhold opretholder de enorme lønforskelle og akkumulationsbetingelser i verden. Japan er her et indlysende eksempel: den gennemsnitlige produktivitet er ganske vist lav sammenlignet med f.ex. USA og Vesttyskland, mens arbejdskraftens pris er lavere, inklusive i de brancher hvor den japanske produktivitet er højere. Det sidste gælder f.ex. stålværkerne hvor produktiviteten i Japan er højere end i USA, samtidig med at lønningerne er lavere.

Endvidere vil vi undgå at betegne ovenstående som en "modifikation af værdilovens gennemslag på verdensmarkedet", fordi dette implicerer at den historisk har slået igennem, men nu modificeres, mens det vigtige er at fastslå, hvilke tendenser der er til at værdiloven kommer til at slå igennem på verdensmarkedet. Dette skal vi vende tilbage til nedenfor.

Vi medtager et tænkt eksempel for at gøre vores standpunkt klart. 
USA's gennemsnitlige produktivitet sættes til 1, Japan's til 0,5. Valutakursen mellem de to lande sættes til $1 \$=1$ Y som udtryk for at een "gennemsnitsvare" i USA koster 1 \$ og een "gennemsnitsvare" i Japan koster 1 yen. Nu tænker vi os fire brancher parvis i begge lande, bil, kemi, radio og stålbrancherne.

\section{Forskellige branchers produktivitet i forhold til den gennemynitlige natio- nale produktivitet}

\begin{tabular}{lcccc}
\hline & \multicolumn{2}{c}{ USA } & \multicolumn{2}{c}{ JAPAN } \\
Branche & \multicolumn{2}{c}{ (Gnmsnt. Prdkt. 1,0) } & \multicolumn{2}{c}{ (Gnmsnt. Prdkt. 0,5) } \\
\cline { 2 - 5 } Bil & Prdkt. & Pris S & Pris Y & Prdkt. \\
\hline Kemi & 2,0 & 0,5 & 2,0 & 0,5 \\
\hline Radio & 1,0 & 1,0 & 1,0 & 1,0 \\
\hline Stål & 0,5 & 2,0 & 0,5 & 2,0 \\
\hline
\end{tabular}

(Alle tal er tænkte)

Produktiviteten er her bestemt som et sammenfattende udtryk for arbejdsproduktivitet, kapitalproduktivitet og profitrate, således som produktiviteten groft sagt kan måles som bruttonationalprodukt divideret med arbejdstimer.

Det synes som om ækvivalentbyttet brydes: en japaner køber amerikansk bil for $0,5 \$$ hellere end en japansk for $2 \mathrm{Y}$, fordi sidstnævnte er fire gange dyrere, men betaler med 0,5 Y hvilket repræsenterer halvt så meget arbejde som $0,5 \$$. Sagen er blot at dette dobbelte arbejde som japaneren tilsyneladende skaffer sig, ikke kan realiseres som sådan. Amerikaneren der "kun" har fået de $0,5 \mathrm{Y}$ for sin bil, har stadig sin 0,5 \$ eller en japansk radio til 0,5 Y.

Noget andet er at en smart amerikaner kan forsøge sig med at sælge sin amerikanske radio for $2 \$$, købe 4 japanske for $2 \mathrm{Y}$ og derefter sælge dem igen som om de var amerikanske for $8 \$$, hvorved han snart bliver rig. Denne handelskapitalistiske fusentast realiserer uligheden i de byttede varers indhold af arbejde, hvorved han tilegner sig en del af det samlede amerikanske merprodukt. På samme måde kan hans japanske kollega tilegne sig en del af de japanske, hvis han gør sig i biler.

I virkelighedens verden er det netop på denne måde handelskapitalen kan skyde sig ind og berige sig gennem ikke-ækvivalentbyttet. Men i samme virkelighedens verden vil konkurrencen i det lange løb sænke den japanske radios 
pris på det amerikanske marked og dermed tvinges den amerikanske radiobranche til at hæve produktiviteten. Samtidig vil staten træde til med protektionistiske forholdsregler hvis "hjemlige arbejdspladser er truede" ect. Vores eksempel ligner fra dette synspunkt en regulær handelskrig.

Det er værd at gøre opmærksom på at handelskapitalen ikke skal opfattes som specielle kapitaler der specialiserer sig i handel. Sådanne findes også, men der kan alligevel være tale om produktive kapitaler der samtidig øjner chancen for lette profitter. Her er de multinationale selskaber iøjnefaldende, fordi de samtidig med at være nogle af de mest avancerede produktive selskaber, ekselerer i allehånde handelsprofitter, fx. valutaspekulation. Det er gerne de multinationale selskabers praksis som handelskapitaler der bliver kritiseret, mens deres aktiviteter på det produktive område er progressivt og udemærket, tænk blot på gruppearbejde og "medbestemmelse", for slet ikke at tale om højproduktiv napalm.

Stadig udfra det noget ekstreme eksempel fremgår det at valutaudvekslingssystemet og verdenspenge problemet må forstås udfra denne specielle sammenhæng der er mellem de nationale penge og den gennemsnitlige nationale produktivitet på den ene side, og de enkelte branchers udvikling på den anden. De to må tilstadighed holdes adskilt for ikke at bringe argumentationen ind i blindgyder.

Mellem de kapitalistiske lande der har frit konvertible valutaer, vil der dannes en verdensmarkedspris på en branches varer. Denne pris vil dog repræsentere mange forskellige mængder arbejde, alt efter hvilken national kapitalisme der har produceret varen. Derfor er det netop ikke en pris i kapitalistisk forstand, men snarere en handelskapitalistisk udbud/efterspørgsels pris, der som sagt ikke svinger omkring varens værdi, fordi verdensmarkedets indretning tillader at varer der indeholdende forskellige mængder arbejde byttes lige over. Konkurrencen på pris på verdensmarkedet tvinger således kun branchen i et enkelt land til at hæve produktiviteten, hvis denne branche samtidig er lavproduktiv i forhold til det nationale gennemsnit.

Egentlige verdenspenge i samme forstand som nationale penge, er set herudfra endnu en umulighed. Der eksisterer ikke idag en gennemsnitlig verdensproduktivitet, fordi en sådan ikke har mening før internationale brancher dominerer ved at påtvinge en universel profitrateudligning.

Det problem der ligger $i$ at fastlægge valutakurserne tilstrækkelig konstant til afvikling af verdensmarkedets udvekslinger og til at dæmpe spekulationsbølger, kunne tidligere delvist løses med guldstandarden, men derfor var guldet ikke verdenspenge i egentlig forstand. Gu ldet var nødvendigt sålænge verdensmarkedets hovedlandes gennemsnitlige produktivitet var meget forskellig, men med den udligning der har fundet sted efter II verdenskrig og tendensen til dannelse af internationale brancher, der ingen tendentielt virkeliggør egen- 
tlige verdenspenge, bliver det muligt at opretholde et valutasystem uden guldets indbyggede tvang. At det volder centralbankdirektørerne og IMF hovedbrud er ingen årsag til at marxister skal sove dårligt om natten.

\section{RESULTATER OG PERSPEKTIVER}

Den mest inspirerende bog vi har læst om verdensmarkedsproblemerne er Christel Neusüss "Imperialismen og det kapitalistiske verdensmarked" ${ }^{60}$ Hun når frem til en lang række afgørende problemstillinger. Vi mener dog at hun kunne komme endnu længere, hvis hun tog fat på en historisk specificering af begreberne om verdensmarkedet. Hendes fremstilling bygger på to grundantagelser: 1) at verdensmarkedet er frembragt af kapitalen; 2) at grundlaget for forståelsen af værdilovens modificering på verdensmarkedet er kategorien 'ekstramerværdi". Vi mener ikke at disse to antagelser holder.

Vi har argumenteret for at verdensmarkedet ikke slet og ret kan forståes som frembragt af kapitalen. Heraf følger at "værdilovens modificerede virkninger på verdensmarkedet" til dels er en falsk problemstilling. Kapitalen reproducerer sig ikke modificeret på verdensmarkedet, men udvikler et kapitalistisk verdensmarked i kamp mod den feudale nation. Det er situationen idag. Ekstramerværdien og hele diskussionen om den, opløser sig i tidsfaktoren: hvor lang tid kan værdi og prisudtryk undgå at falde sammen (i krisen)? Her er det mest tydeligt at Christel Neusüss ville kunne komme frem til virkelig spændende resultater, ved en analyse af verdensmarkedskriserne i de sidste 200 år. Hun er nødt til at have det perspektiv, for at få bevægelserne i verdensmarkedets konstitution tydeligt frem. Vi savner en historisk specificering af ekstramerværdiens virkninger. Det metodiske grundlag for ekstramerværdien kan diskuteres, men det bliver let ordfægteri, hvis man ikke forsøger at specificere den historisk (om det metodiske, se vores indledning).

Vi har heller ikke udført disse historiske undersøgelser, men planlægger at gøre det. ${ }^{61}$ På baggrund af vores hidtidige arbejde kan vi dog godt komme med

60. Christel Neusüss: Imperialismen og det kapitalistiske verdensmarked, Kurasje 1976.

61. Den linie vi har begyndt i Statens Historie, 1 \& 2 fører vi videre. Næste emne bliver Englands industrielle revolution og udviklingen af den industrielle borgerlige stat, og parallelt hermed udviklingen i USA. Den moderne imperialisme vil først blive behandlet i senere projekter ud fra et omfattende historisk materiale. 
nogen antagelser om verdensmarkedet idag, og forholdet mellem den nationale og internationale cirkulation.

Christen Neusüss citerer på s. 99 Marx' arbejdsplan for "udviklingen af det borgerlige samfunds totalitet på følgende måde: udgående fra den kapitalistiske produktions formbestemmelser vil han fremstille "produktionenes indre organisering", derefter dens "sammenfatning i staten", så "det internationale forhold" og endelig "verdensmarkedet som afslutning" ". ${ }^{62} \mathrm{Ud}$ fra denne plan kan vi perspektivere vores hidtidige resultater.

Den kapitalistiske produktions "indre organisering" er udviklingen af kapitalismens mindste virkelighed. Her er udgangspunktet det historiske udgangspunkt, dvs. den simple varecirkulation - hvad der skyldes den dialektiske fremstillings krav om historisk specifikation af begreberne. Vi udviklede den dialektiske fremstillings grundbestemmelser igennem den enkle subsumtion. Derefter fulgte en skitse af feudalismens udvikling. Her analyserede vi pengeformens udvikling, herunder udviklingen af de falske kapitalformer (handels- og ågerkapital) der ikke er udgangspunktet for den merværdiproducerende kapital. Merværdiproduktionen blev forudsat accepteret som kapitalismens essens. Kapitalismens mindste virkelighed blev herudfra udviklet som branchen. Dette arbejde bestod i en udvidelse og kritik af Marx' historiske materiale om udviklingen til og med den industrielle revolution i England, i Kapitalens første bind. Herunder unders $\emptyset$ gte vi opkomsten af de første brancher. Den nationale gennemsnits profitrates virkeliggørelse og de nationale industrielle revolutioner skal undersøges. Vi analyserede statens udvikling som en subsumtionshistorie og nåede frem til en relativt nuanceret bestemmelse af sammenhængen mellem de embryonale brancher og de borgerlige revolutioner; de merkantile borgerlige nationalstaters fremvækst imellem det feudale verdensmarkeds pres og presset fra kontinuum 2. Herefter kan vi kun opstille mere løse hypoteser. Den industrielle borgerlige nationalstat opstår som en komplex subsumtion af den merkantile borgerlige stat (hhv. kongestat ved overgangen til konstitutionelt monarki) under kontinuum 2. Hermed muliggøres udviklingen af en kapitalistisk produceret arbejderklasse. Arbejderbevægelsen og -partierne udvikler sig og integreres i den borgerlige stat og offentlighed. De ender som statsbærende instanser i den nationale socialstat, efter I verdenskrig.

Den borgerlige nationalstat er derfor kapitalismens udvikling indenfor en feudal ramme. Grunden til at kapitalen ikke uden videre overskred denne feudale rest skal søges i sammenhængen mellem udbytning og undertrykkelse. Selvom brancherne søgte ud over de nationale rammer helt fra starten (rederbranchen, jernbanebranchen, kommunikationsbranchen osv.), så var integratio-

62. Neusüss, s. 99 cit K. Marx, Grundrisse, s. 139. 
nen af arbejderklassen altid bagefter branchens udvikling. Dette skyldtes simpelthen at arbejderklassen først kunne produceres kapitalistisk når arbejdere havde produceret alle reprodukionsbrancherne og samtidig at den relative merværdiproduktion var så fremskreden at denne sektors produkter kunne købes af arbejderklassen.

Denne tidsforskydning gjorde det permanent nødvendigt for kapitalisterne at opretholde undertrykkelsen igennem staten; og den var nationalt defineret af dens subsumtionshistorie. At enkelt-kapitalerne derfor blev sammenfattet i nationalstaten, skyldtes ikke den kapitalistiske produktions indre organisering, men den almene ækvivalents fordobling i penge og stat. I denne dobbelte form præsenterede den nationale ramme sig overfor den kapitalistiske produktions indre organisering - branchen, som et givent historisk udgangspunkt for kapitalismens opståelse. Dels som penge: dvs. at kapitalen i en af sine tilstandsformer var konstitueret som del af de nationale penge; dels når branchens arbejdere stod overfor kapitalen i dens tilstand som penge, var pengene en manifestation af den ufri samfundsmæssiggørelse den almene ækvivalent udtrykte i klassesamfundet. Derfor blev udbytningen nok defineret i rene kapitalistiske termer, men undertrykkelsen blev båret af de nationale penge og den nationale stat, og dette forhold konstituerede kapitalen som national totalkapital. Kapitalens umiddelbare undertrykkelse gik kun til fabriksporten. Derefter stod kapitalen kun overfor arbejderne i form af penge. Dermed var det givet at kapitalens samfundsmæssige undertrykkelse måtte benytte sig af den overleverede undertrykkelses struktur, der lå i pengenes fordobling i penge og stat. Derfor var kapitalen tvunget af de "historiske omstændigheder" til at konstituere sig som national totalkapital. For at opretholde undertrykkelsen (for at oprette den overhovedet) måtte kapitalen lade sin gennemsnits profitrate binde af en given national valuta, dvs. lade nationalstaten være fixpunktet mellem undertrykkelse og udbytning.

Vi kommer så til det internationale forhold. Marx adskiller dette fra "verdensmarkedet", og det vil vi opfatte således at "verdensmarkedet" er det $k a$ pitalistiske verdensmarked, der står i modsætning til det historiske realiserede forhold mellem de feudalt-nationalt definerede kapitalismer. Den fundamentale forskel der er mellem den nationale og internationale cirkulation er selvfølgelig nationalstaten. Men vi er helt uenige med Christel Neusüss, når hun derefter, uden nogen nærmere argumentation, gør den almindelige, men forkerte, antagelse om verdensmarkedet som frembragt af kapitalen, til grundlaget for sin analyse.

Kapitalen har frembragt brancherne, - og efter deres natur vil deres grænsel $\varnothing$ se akkumulation drive dem ud over de nationale skranker. Brancherne er derfor principielt internationale og pr. branche dannes der tendentielt internationale markedsværdier. Disse tendenser modvirkes af den undertrykkelses-betingede 
nationale gennemsnits profitrate, som på verdensmarkedet eksisterer som nationale valutaer. Vi har gennemgået dette i afsnittet om verdenspengene. Den nationale cirkulation er således karakteriseret ved eksistensen af branchebestemte markedsværdier og samtidig en national gennemsnits profitrate (P'). I det nationale system dominerer derfor den industrielle kapital, fordi handelskapitalen er underlagt den nationale $\mathrm{P}$ 'ved nationale transaktioner.

Den internationale cirkulation er karakteriseret ved de internationale branchers markedsværdiers modificerede gennemslag i de nationale valutaers udvekslingsforhold. Da der derfor ikke er nogen universel almen ækvivalent, er der ingen universel P'. Konsekvensen af dette er at handelskapitalen har spillerum i det meste af den internationale cirkulation, undtagen i de allerede eksisterende internationale brancher. Dette viser sig ved at de fleste varer på verdensmarkedet cirkulerer som varer, og ikke som kapital. De fleste af de forhold der omtales som imperialisme kan føres tilbage til handelskapitalens dominans på verdensmarkedet.

Christel Neusüss har enormt svært ved at forklare udviklingen af en international P', som en udvikling fra de nationale P'. Det er da heller ikke et korrekt billede af den virkelige udvikling. I sin forklaring benytter hun sig af de gængse opdelinger i enkeltkapital contra national total-kapital. Denne opdeling er forkert fordi den historiske bevægelse går fra branchen, der i sin natur er international, men i kraft af den nationale konstitution af den almene ækvivalent og dermed af P', bevæger sig som en national totalkapital over arbejderklassen, men ikke på verdensmarkedet (undtagen i direkte krig).

Den samtidige eksistens af simpelt varebytte, falske kapitalformer, nationalstatslige valutaer og internationale brancher på verdensmarkedet, i den langsigtede historiske udvikling af den universelle P', dvs. merværdiproduktionens endelige, universelle virkeliggørelse, kan Christel Neusüss ikke specificere historisk indenfor begrebsparret enkelt-kapital/national total-kapital. Hendes manglende erkendelse af dette punkt sætter sig mange spor i hendes opfattelse af verdensmarkedets konstituering. Hun differentierer ikke mellem handelskapital og industrikapital, og handelskapitalens dominans på verdensmarkedet op til den nuværende verdenskrise, kan derfor ikke udledes som konsekvens heraf. Oprettelsen af den nationale P' forudsætter selvfølgelig afvikling af de indre feudale skranker, men oprettelsen af den internationale P', er ikke kapitalismens kamp mod feudalismen, men derimod de internationale branchers kamp mod de nationale kapitalismer, som en specifik forening af kapitalismens virkeliggørelse i en national P' og den feudale enhed nationen.

Det er ikke nationalstaterne der smelter sammen på verdensmarkedet, men de nationalt begrænsede brancher, der vokser ud over den feudale nation og bliver internationale. Gangen i den historiske udvikling er altså ikke branche (markedsværdi), så national P' og endelig en verdens P'. 
Derimod er den samtidig fra branche til national P' $o g$ fra branche via international markedsværdi til verdens P'. Det er ikke en national $\varnothing$ konomi som helhed, der smelter sammen med andre komplette nationale økonomier, men specifikke brancher der bryder ud af den nationale sammenhæng, og udvikler en direkte konkurrencekamp - en international markedsværdi. Fx. skibsværfterne, hvor den reale eksistens af en international markedsværdi indhenter de lavproduktive skibsværfter overalt på jordkloden, og dræber dem, mens de nationale stater må ødelægge ethvert ækvivalentbytte, som den feudale enhed de er, for at redde "danske" værftsarbejdere på "koreanske" eller "brasilianske" værftsarbejderes bekostning.

Her er der kun peget på et par punkter i Christel Neusüss fremragende bog. Det er vores håb, at den diskussion hun lægger op til, vil blive ført videre. Bestemmelsen af kapitalismens alder og vitalitet er for os et klart internationalt spørgsmål. Derfor må diskussionen af verdensmarkedet være central for denne bestemmelse. Vi håber endvidere, at vi har demonstreret nogle af de store muligheder der ligger i den historiske specificering af spørgsmålet om kapitalismens alder og vitalitet.

Vi er fuldstændigt klar over, at vi har bevæget os ud på et kæmpe område, og at vi mange gange har gyngende grund under fødderne. Artiklens centrale tema har været propaganda for en marxisme, der afkræver sig selv en bred og konsekvent historisk specificering af de dialektiske begreber. Vi tror, det er den vej, man skal gå for at kunne diskutere kapitalismens alder og vitalitet uden illusioner - hvad enten den går på real-abstrakte væsner, kapitalismens fulde udvikling og snarlige sammenbrud eller marxismens afgørende betydning for den revolutionære afskaffelse af dette Molokkens rige. Gå på to ben og vær med til at oprette den nye virkelighed.

Veddinge maj '78 \& Christiania oktober '78.

Hjalte Tin Iversen

Fabrikken, Christiania

Bådsmandsstræde 43

1407 København K.

(01) 547894
Jens Herskind \&

Thomas Andersen

Storkelunden 9

4540 Fårevejle

(03) 453517 